REVIEW ARTICLE

https://doi.org/10.1038/s41467-019-11450-z

\title{
Subseafloor life and its biogeochemical impacts
}

\author{
Steven D'Hondt (iD ${ }^{1}$, Robert Pockalny (iD) ${ }^{1}$, Victoria M. Fulfer (i) ${ }^{1} \&$ \\ Arthur J. Spivack ${ }^{1}$
}

Subseafloor microbial activities are central to Earth's biogeochemical cycles. They control Earth's surface oxidation and major aspects of ocean chemistry. They affect climate on long timescales and play major roles in forming and destroying economic resources. In this review, we evaluate present understanding of subseafloor microbes and their activities, identify research gaps, and recommend approaches to filling those gaps. Our synthesis suggests that chemical diffusion rates and reaction affinities play a primary role in controlling rates of subseafloor activities. Fundamental aspects of subseafloor communities, including features that enable their persistence at low catabolic rates for millions of years, remain unknown.

S ubseafloor ecosystems constitute a significant portion of Earth's biosphere. The estimated total number of cells in marine sediment $\left(\sim 10^{29}\right)^{1}$ rivals estimated totals in the ocean and in soil ${ }^{2}$. Although total cell abundance is unknown for the igneous aquifer that underlies marine sediment, microbes are routinely recovered from this aquifer ${ }^{3}$, chemical traces of their activity are pervasive in its altered rock ${ }^{4,5}$ and formation fluid ${ }^{6}$, and physical textures suggestive of microbial alteration are common ${ }^{7}$. The total volume of subseafloor habitats is immense; the volumes of marine sediment and igneous basement cooler than $122^{\circ} \mathrm{C}$ [the currently accepted high-temperature limit to life $\left.{ }^{8}\right]$ are respectively $2.6 \times 10^{8} \mathrm{~km}^{39}$ and $1.0 \times 10^{9} \mathrm{~km}^{3}$ (Methods). The volumes of potentially habitable void space within the sediment ${ }^{9}$ and basement, respectively, are about $8.5 \times 10^{7} \mathrm{~km}^{3}$ and $8.0 \times 10^{7} \mathrm{~km}^{3}$ (each equal to about $6 \%$ of ocean volume $\left.\left[1.3 \times 10^{9} \mathrm{~km}^{3}\right]^{10}\right)$.

Mean respiration per cell is very low in subseafloor sediment ${ }^{11,12}$. Although their total abundance is high, microbial cells in marine sediment are generally much smaller than microbial cells in the surface world. Consequently, the total biomass of marine sedimentary life is $<1 \%$ of Earth's total biomass ${ }^{1}$. Per-cell catabolic rates and total biomass are presently unknown for microbial communities in the igneous aquifer beneath the sediment.

Because subseafloor communities reside at the interface between the biologically active surface world and the large geological reservoirs of biologically important chemicals, subseafloor microbial activities play a fundamental role in Earth's biogeochemical cycles. This role is particularly visible in the organic-fueled activity of marine sedimentary life. Burial of reducing power (electron donors) in the form of organic matter and pyrite $\left(\mathrm{FeS}_{2}\right)$ is the principal driver of Earth's surface oxidation over geologic time ${ }^{13}$. Subseafloor life is the last biological filter through which organic matter passes on its way to burial and subduction. Among Earth's surface and near-surface environments, marine sediment is the largest reservoir of carbon (including both the reduced carbon in organic matter and the oxidized carbon in sedimentary carbonates) ${ }^{14}$ and the third largest reservoir of nitrogen (after the atmosphere and continental crust) ${ }^{15}$.

The general geography of subseafloor catabolic activity is well constrained. Anaerobic activity dominates in the fast-accumulating sediment of continental margins and oceanic upwelling

\footnotetext{
${ }^{1}$ Graduate School of Oceanography, University of Rhode Island Narragansett Bay Campus, 215 South Ferry Road, Rhode Island 02882, USA. Correspondence and requests for materials should be addressed to S.D. (email: dhondt@uri.edu)
} 
regions, where subseafloor respiration greatly outpaces the flux of dissolved oxygen $\left(\mathrm{O}_{2}\right)$ into the sediment from the ocean. Aerobic activity dominates in the very slowly accumulating sediment of the deep open ocean, where subseafloor respiration rates are very low and the $\mathrm{O}_{2}$ flux keeps pace with respiration throughout the sediment column ${ }^{16}$ (Fig. 1). Rates of organic-fueled activity are highest in young, near-seafloor sediment and decline rapidly with increasing depth below seafloor ${ }^{17}$ (Fig. 2). Similarly, oxidation of igneous ocean crust is fastest for young crust (less than circa 10 $\mathrm{Ma})$ and relatively slow thereafter ${ }^{18}$. Crustal oxidation is generally greatest where permeability is highest and seawater flow through the igneous aquifer is consequently fastest ${ }^{19}$. This is typically in discrete zones within the upper $200-500 \mathrm{~m}$ of the igneous sequence $^{20}$ (Fig. 3).

Given the ubiquity of subseafloor life and its central role in chemical exchange between the surface and subsurface worlds, this review has three major objectives. The first objective is to synthesize present understanding of subseafloor microbes, their catabolic activities, and their global consequences. The second objective is to advance understanding of the factor(s) that ultimately limit rates of subseafloor activities. The third objective is to identify major gaps in scientific understanding of subseafloor communities and activities, and recommend approaches to filling those gaps.

Diversities of subseafloor organisms and activities. Subseafloor sediment and the underlying basaltic aquifer are inhabited by many lineages of Bacteria ${ }^{21-23}$, Archaea ${ }^{22,23}$, and a subset of the Eukarya (fungi) 24,25 . Transcriptional data indicate that members of all three domains are active in subseafloor sediment ${ }^{25}$. Viruses are also abundant in both the sediment ${ }^{26}$ and the basaltic aquifer ${ }^{27}$.

Due to low per-cell energy fluxes ${ }^{28}$, selection is fierce in subseafloor sediment, leading both microbial diversity ${ }^{29}$ and cell concentration $^{1}$ to decline exponentially with sediment depth and age. Broadly defined taxonomic groups (Chloroflexi, Deltaproteobacteria, Firmicutes) are present in relatively cool subseafloor sediment throughout much of the ocean $22,23,29-34$, suggesting that the consequences of this selection are relatively consistent at coarse taxonomic levels.

Geographic distributions of taxonomic richness and microbial abundance are largely unknown for the subseafloor igneous aquifer. However, different habitats within this environment are known to harbor distinctly different communities. For example, hot $\left(65^{\circ} \mathrm{C}\right)$ anoxic fluid in $3.5-\mathrm{Ma}$ basalt of the Juan de Fuca Ridge (northeastern Pacific) contains abundant thermophilic anaerobes 3,35 , while relatively cold $\left(3-4^{\circ} \mathrm{C}\right)$ oxic fluid of the North Pond aquifer (central North Atlantic) is dominated by diverse Proteobacteria ${ }^{36,37}$. Communities from both aquifers are dominated by bacteria, with only trace concentrations of archaea $^{35,37}$.

Subseafloor organisms glean energy from a broad range of redox reactions (e.g., disproportionation reactions, such as fermentation, and respiration reactions). In both the sediment and the igneous basement, electron acceptors (oxidants) for respiration include dissolved chemicals $\left(\mathrm{O}_{2}\right.$, nitrate $\left[\mathrm{NO}_{3}{ }^{-}\right]$, sulfate $\left[\mathrm{SO}_{4}{ }^{2-}\right]$ ) carried by diffusion or flow into the subseafloor, oxidized elements in minerals, and hydrogen peroxide $\left(\mathrm{H}_{2} \mathrm{O}_{2}\right)$ from water radiolysis. In sediment, electron donors (reductants) include organic matter and reduced minerals deposited from the

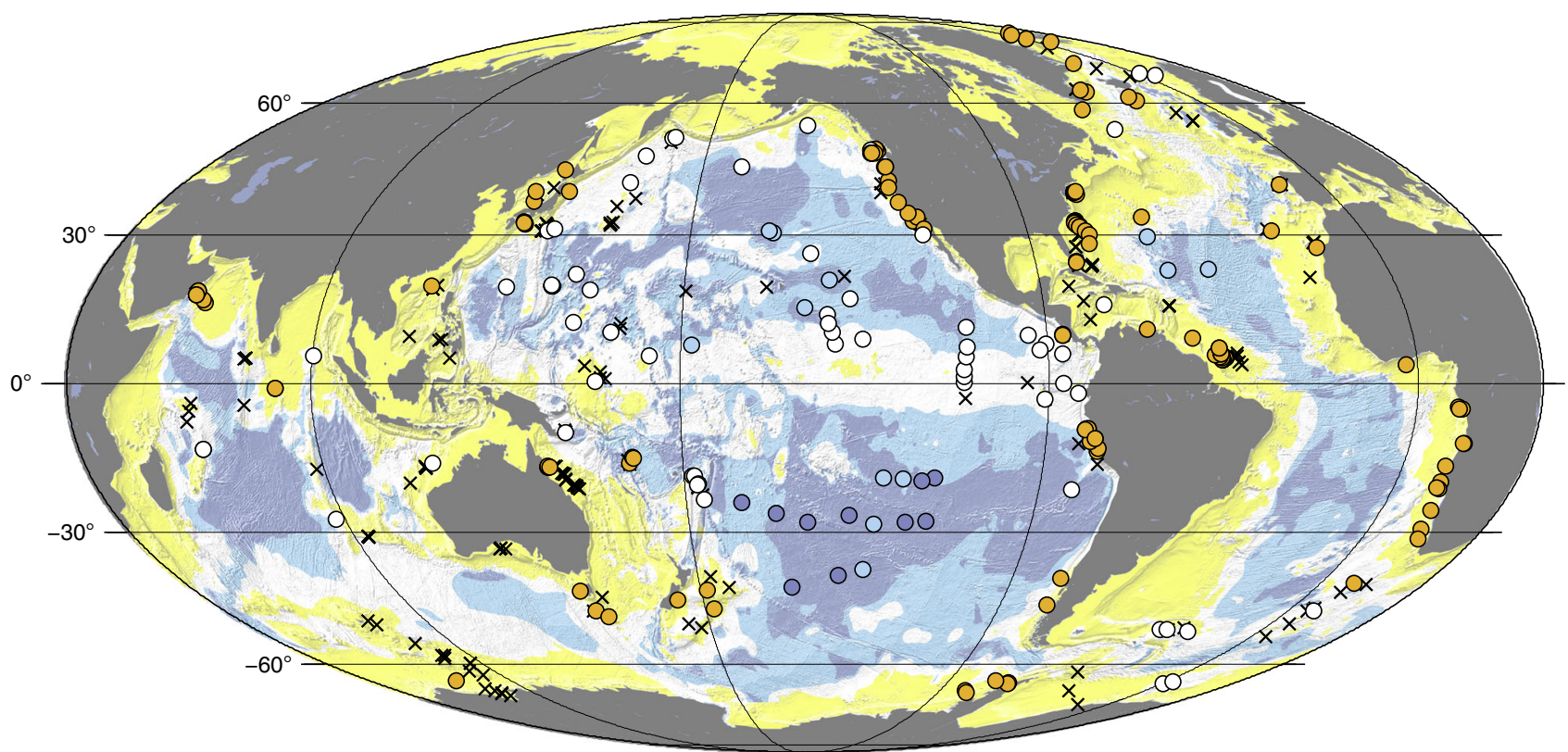

Fig. 1 Global distributions of dissolved $\mathrm{O}_{2}$ and $\mathrm{SO}_{4}{ }^{2-}$ in subseafloor sediment. In yellow regions, dissolved $\mathrm{SO}_{4}{ }^{2-}$ is expected to disappear within the sediment and $\mathrm{HCO}_{3}{ }^{-}$is expected to be the predominant net electron acceptor at greater depths. In white regions, dissolved $\mathrm{SO}_{4}{ }^{2-}$ is expected to penetrate throughout the sediment, from seafloor to igneous basement. Dark blue and light blue regions respectively represent the minimum and maximum areas over which dissolved $\mathrm{O}_{2}$ is expected to penetrate throughout the sediment from seafloor to basement ${ }^{16}$. $\mathrm{SO}_{4}{ }^{2-}$ reduction is expected to dominate net subseafloor organic oxidation in the yellow and white regions. $\mathrm{O}_{2}$ reduction is expected to dominate net subseafloor organic oxidation in the blue regions. Orange dots mark drill sites where $\mathrm{SO}_{4}{ }^{2-}$ disappears within the first 500 meters of sediment. White dots mark drill sites where $\mathrm{SO}_{4}{ }^{2-}$ penetrates the entire sediment sequence. Dark blue dots mark drill sites where dissolved $\mathrm{O}_{2}$ and dissolved $\mathrm{SO}_{4}{ }^{2-}$ penetrate the entire sediment sequence. Medium blue dots mark coring sites where $\mathrm{O}_{2}$ and $\mathrm{SO}_{4}{ }^{2-}$ penetrate to the bottom of the cores (meters to tens of meters) and may penetrate to basement. $\mathrm{X}$ symbols mark sites where the full extent of $\mathrm{SO}_{4}{ }^{2-}$ penetration is unknown, because $\mathrm{SO}_{4}{ }^{2-}$ is present in all measured samples, but the sedimentary sequence continues far below the last measurement. More information regarding the generation of this map is available in the Methods section 


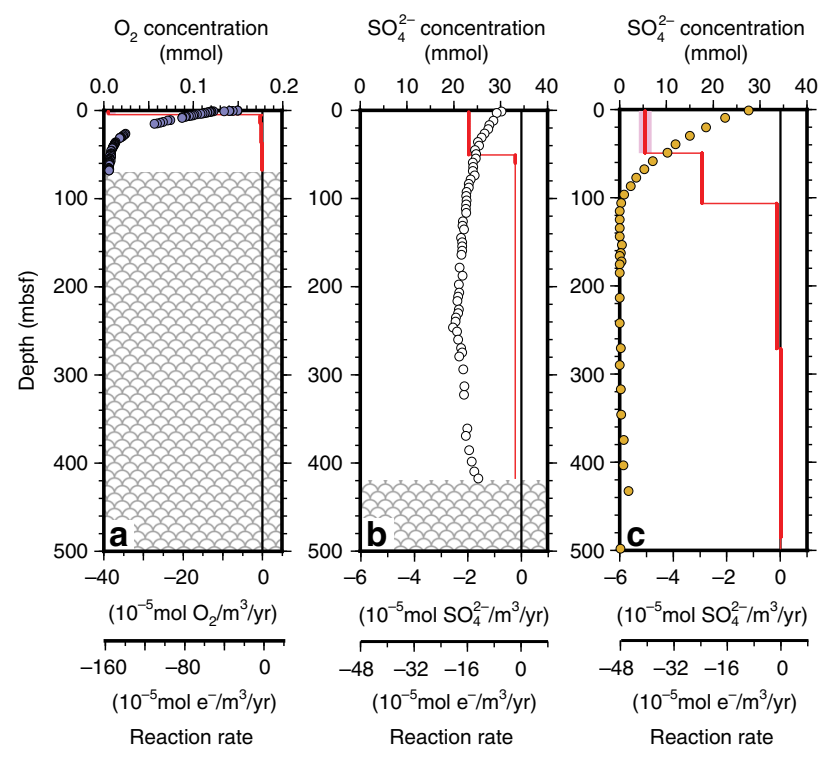

Fig. 2 Profiles of net respiration rates at representative sites. a Profile of net respiration rate $\left(\mathrm{O}_{2}\right.$ reduction rate) as a function of sediment depth at oxic IODP Site U1370 (dark blue zone in Fig. 1). b Profile of net respiration rate $\left(\mathrm{SO}_{4}{ }^{2-}\right.$ reduction rate) as a function of sediment depth at anoxic ODP Site 1226, where dissolved $\mathrm{SO}_{4}{ }^{2-}$ is present throughout the sediment column (white zone in Fig. 1). c Profile of net respiration rate $\left(\mathrm{SO}_{4}{ }^{2-}\right.$ reduction rate) as a function of sediment depth at anoxic ODP Site 984, where dissolved $\mathrm{SO}_{4}{ }^{2-}$ is depleted at a relatively shallow sediment depth (yellow zone in Fig. 1). Circles mark chemical concentration data color-coded to the Fig. 1 geographic zones in which the sites occur (dark blue, white and yellow, respectively). Red lines mark net respiration rates and pink bars mark uncertainty (first standard deviation). Crosshatched zones in A and B mark igneous basement

overlying world ${ }^{28}$, and hydrogen $\left(\mathrm{H}_{2}\right)$ from in situ radiolysis of water ${ }^{38}$. In the igneous crust, electron donors include reduced elements in the rock (which originated in the underlying mantle $)^{18}$, dissolved organic matter that enters with water from the overlying ocean ${ }^{6}$, and $\mathrm{H}_{2}$ from in situ water radiolysis ${ }^{39}$. Although in situ radiolysis may support subseafloor respiration in both the sediment and the underlying igneous aquifer, it may not have a net effect on subseafloor chemistry or global biogeochemical cycles, because it simultaneously creates reductant $\left(\mathrm{H}_{2}\right)$ and oxidant $\left(\mathrm{H}_{2} \mathrm{O}_{2}\right.$ and oxidized mineral species) in stoichiometric balance.

The traditional model of subsurface respiration assumes successive zones of reduction of $\mathrm{O}_{2}, \mathrm{NO}_{3}{ }^{-}$, oxidized manganese ( $\mathrm{Mn}[\mathrm{IV}])$, oxidized iron (Fe[III]), $\mathrm{SO}_{4}{ }^{2-}$, and carbon dioxide $\left(\mathrm{CO}_{2}\right)$ with increasing distance from the oxic surface world. In marine sediment, this sequence is vertical, with increasing depth below seafloor ${ }^{40,41}$ (Box 1). In aquifers with active fluid flow, the sequence depends on distance from the location where the fluid enters the aquifer from the surface ${ }^{42}$, e.g., the location where seawater enters the subseafloor igneous basement.

Most metabolic activities known to occur in subseafloor ecosystems were first discovered in surface or near-surface ecosystems. However, a few were first discovered in subseafloor sediment, including anaerobic oxidation of methane ${ }^{43}$, sulfatereducing ammonium oxidation ${ }^{44}$, and microbial production of ethane and propane ${ }^{45}$.

The specific taxa responsible for individual metabolic activities are not yet known for most subseafloor environments ${ }^{46}$. The taxa responsible for specific activities may vary considerably in space and time; a recent metagenomic study of subseafloor planktonic

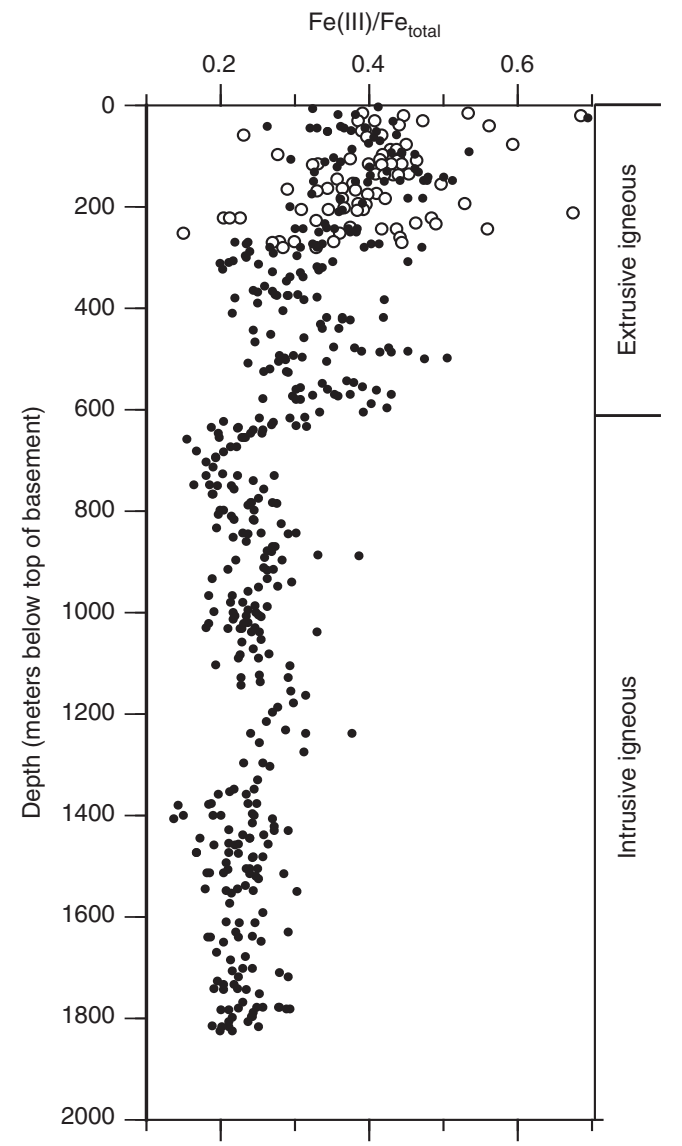

Fig. 3 Profile of Fe oxidation ratio $\left[\mathrm{Fe}(\mathrm{III}) / \mathrm{Fe}_{\text {total }}\right]$ as function of basement depth. $\mathrm{Fe}_{\text {total }}=\mathrm{Fe}(\mathrm{III})+\mathrm{Fe}(\mathrm{II})$. Higher ratios of $\mathrm{Fe}(\mathrm{III}) / \mathrm{Fe}_{\text {total }}$ show that a larger fraction of the total $\mathrm{Fe}$ is oxidized. Filled circles mark data from DSDP Hole 504B. Open circles mark data from ODP Hole 896 A. All data from Alt et al. ${ }^{20}$. Figure modified from Alt et al. ${ }^{20}$

communities in a cold oxic basalt aquifer found a high degree of metabolic functional redundancy over two years of sample collection, despite large shifts in community composition ${ }^{37}$.

Global consequences of subseafloor biological activities. Subseafloor microbial activity has at least five major consequences for global biogeochemical cycles (Fig. 4). First, it plays an important role in the oxidation-reduction (redox) evolution of Earth's surface and near-surface environments ${ }^{47}$. Burial of organic matter is the principal pathway for removing reduced material from the surface world and subsurface microbial activity limits the rate of organic burial. In other words, subsurface microbial activity is the final throttle on the primary driver of Earth's surface oxidation. Second, pyrite $\left(\mathrm{FeS}_{2}\right)$ produced as a result of microbial $\mathrm{SO}_{4}{ }^{2-}$ reduction in marine sediment is the principal sink for sulfur from the world ocean ${ }^{48}$. Third, this microbially driven pyrite production is a principal source of alkalinity to the world ocean ${ }^{11}$. These consequences of pyrite precipitation are significant for two reasons: sulfate and bicarbonate (the principal contributor to alkalinity) are the second and third most abundant anions in seawater (after chloride) ${ }^{49}$, and alkalinity influences the distribution of $\mathrm{CO}_{2}$ between the atmosphere and ocean by determining the speciation of dissolved inorganic carbon. Fourth, subseafloor $\mathrm{NO}_{3}{ }^{-}$reduction decreases the amount of biologically fixed nitrogen available for marine biomass production (which is often $\mathrm{N}$-limited $)^{50}$. Fifth, subseafloor microbial activities play a 


\section{Box 1 | Co-occurrence of terminal electron-accepting processes}

The standard model of redox zonation in marine sediment assumes successive zones of reduction of $\mathrm{O}_{2}, \mathrm{NO}_{3}{ }^{-}$, oxidized manganese [Mn(IV)], oxidized iron $[\mathrm{Fe}(\mathrm{III})], \mathrm{SO}_{4}{ }^{2-}$ and $\mathrm{CO}_{2}$ with increasing sediment depth. These chemicals, and the material they oxidize, enter sediment at the seafloor; solid phases (manganese- and iron-bearing minerals, organic matter) are deposited with sediment, $\mathrm{O}_{2}, \mathrm{NO}_{3}{ }^{-}$and $\mathrm{SO}_{4}{ }^{2-}$ enter in dissolved form, and most dissolved $\mathrm{CO}_{2}$ is generated in the sediment by organic oxidation.

This succession of redox zones is generally believed to result from thermodynamic competition, in which organisms that use the actively reduced electron acceptor (e.g., $\mathrm{O}_{2}$ ) drive electron-donor concentrations too low to be energetically exploited in combination with less competitive electron acceptors (e.g., $\left.\mathrm{CO}_{2}\right)^{114}$. The successive redox activities have been described as mutually exclusive, with less competitive electron acceptors unused until the most competitive electron acceptor is exhausted ${ }^{41}$. For example, it has been assumed that $\mathrm{SO}_{4}{ }^{2-}$ is not reduced until accessible Fe(III) is exhausted ${ }^{114}$.

This standard model explains many broad patterns of subseafloor metabolism. It explains the near-seafloor succession of net oxidant consumption in anoxic sediment throughout much of the ocean 40,41 . It explains the dominance of oxic respiration over almost $40 \%$ of the seafloor (Fig. 1), where sediment accumulates very slowly and dissolved $\mathrm{O}_{2}$ penetrates the sediment to basement ${ }^{16}$. It explains reversed sequences of net redox activities where oxic seawater diffuses upward into anoxic sediment from the underlying basaltic aquifer $16,21,66$ and where sulfate-bearing water diffuses upward into sulfate-depleted sediment 21,115 .

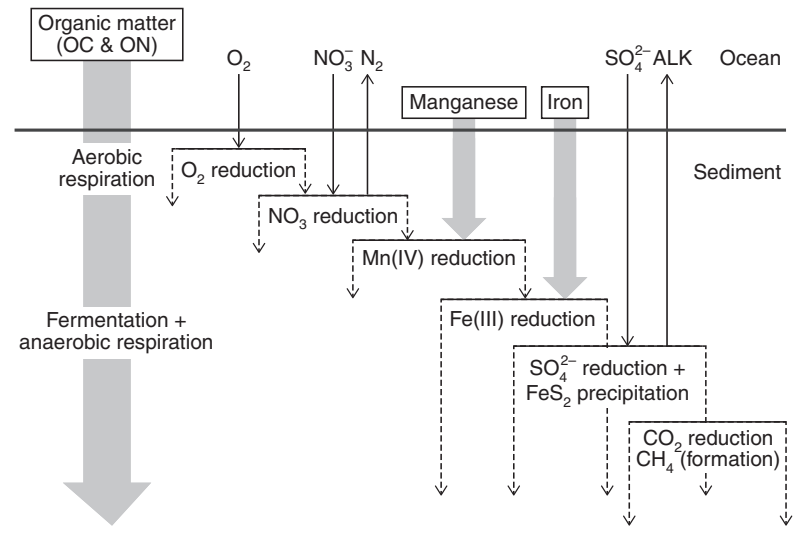

Some patterns of subseafloor respiration modify the standard zonation, but do not necessarily challenge the assumption that the different processes are mutually exclusive. First, discrete zones of net Fe(III) reduction and net $\mathrm{Mn}(\mathrm{IV})$ reduction occur deep beneath zones of net $\mathrm{SO}_{4}{ }^{2-}$ reduction in some sediment ${ }^{21}$. These occurrences can be explained by original deposition of much higher oxidized metal concentrations or much lower organic matter concentration in deep metal-reducing zones than in shallower deposits. Second, isotopic data, transcriptomic data and radiotracer data have respectively been interpreted as evidence of $\mathrm{NO}_{2}{ }^{-}$oxidation ${ }^{116}, \mathrm{NO}_{3}{ }^{-}$reduction ${ }^{25}$ and $\mathrm{SO}_{4}{ }^{2-}$ reduction ${ }^{117}$ in sediment deep beneath the last occurrences of measurable $\mathrm{O}_{2}, \mathrm{NO}_{3}{ }^{-}$and $\mathrm{SO}_{4}{ }^{2-}$. These processes can only occur at these depths if cryptic processes, such as reduction of $\mathrm{H}_{2} \mathrm{O}_{2}$ from water radiolysis ${ }^{38}$, sustain in situ production of the necessary electron acceptors $\left(\mathrm{O}_{2}, \mathrm{NO}_{3}{ }^{-}, \mathrm{SO}_{4}{ }^{2-}\right)$.

A third pattern is consistent with thermodynamic competition, but disproves the assumption that the competing processes are mutually exclusive. As indicated by the dashed arrows in this figure, these processes often co-occur. $\mathrm{O}_{2}$ reduction and $\mathrm{NO}_{3}-$ reduction co-occur at low dissolved $\mathrm{O}_{2}$ concentrations $65 . \mathrm{NO}_{3}{ }^{-}$reduction and $\mathrm{Mn}(\mathrm{IV})$ reduction also often co-occur ${ }^{65}$. $\mathrm{SO}_{4}{ }^{2-}$ reduction and methanogenesis commonly co-occur in marine sediment ${ }^{11,28,45}$, along with $\mathrm{Fe}(\mathrm{III})$ reduction ${ }^{28}$, throughout sequences that span hundreds of meters and were deposited over millions of years. Fe(III) reduction has also been observed in the methanogenic zone $\mathrm{e}^{42}$ and the sulfate-reducing zone of continental aquifers ${ }^{118}$.

Studies of $\mathrm{SO}_{4}{ }^{2-}$ reduction, $\mathrm{Fe}(\mathrm{III})$ reduction and methanogenesis indicate that where these processes co-occur, they may compete for electron donors but operate at the same in situ energy of reaction ${ }^{28}$. This in situ energy closely matches the minimum reaction affinity, $A(A=-\Delta G \text { of the reaction })^{119}$, believed necessary for an organism to sustain an energy-conserving reaction $77,108,109$. Estimates of minimum affinities of energy-conserving anaerobic reactions are generally in the range of $2-5 \mathrm{~kJ}$ per mole of electrons transported 77,109 . Affinities in this range have been observed for multiple reactions in both shallow 44,77 and deep 28,44 marine sedimentary ecosystems.

Co-occurrence of these competing reactions may aid the organisms that rely on them, by removing reaction products and/or creating reactants. Such removal and/or creation may amplify rates of community activity by returning affinities of multiple reactions to the minimum values required to harvest the reaction energy. For example, co-precipitation of dissolved Fe(II) and dissolved sulfide increases affinities of both $\mathrm{Fe}(\mathrm{III})$ reduction and $\mathrm{SO}_{4}{ }^{2-}$ reduction ${ }^{28}$. Oxidation of methane $\left(\mathrm{CH}_{4}\right)$ by $\mathrm{SO}_{4}{ }^{2-}$ reduction or $\mathrm{Fe}(\mathrm{III})$ reduction increases the affinity of methanogenic reactions, enabling methanogens to generate more $\mathrm{CH}_{4}$ that can in turn fuel the sulfate-reducing and $\mathrm{Fe}(\mathrm{III})$-reducing reactions $28,109,118$.

In summary, as each successive electron-accepting process is initiated, it may hold electron donor concentrations too low to be energetically exploited in combination with other electron acceptors ${ }^{114}$. However, this competitive exclusion holds only until the competing reactions yield minimum harvestable affinities of reaction. At least for $\mathrm{Fe}(\mathrm{III})$ reduction, $\mathrm{SO}_{4}{ }^{2-}$ reduction and methanogenesis, concentrations of reactants (including electron donors) and products yield equivalent affinities of reaction and sustain mutually competing processes deep into subseafloor sediment ${ }^{28}$.

significant role in creating and/or destroying resources of economic interest, including marine deposits of hydrocarbons ${ }^{51}$, phosphate $\mathrm{p}^{52}$, dolomite $\mathrm{s}^{53,54}$, and barite ${ }^{55}$.

Impact of subseafloor activity on the global redox budget. Oxidation-reduction (redox) reactions transfer electrons from one chemical to another. This transfer constitutes one of the most significant processes on Earth's surface. The primary driver of redox activity on Earth's surface is oxygenic photosynthesis, which converts water and carbon dioxide into oxidized and reduced compounds $\left(\mathrm{O}_{2} \text { and organic matter, respectively }\right)^{13}$. Organic-fueled respiration reverses this process by oxidizing the organic matter.

Over Earth history, the ocean and atmosphere have been progressively oxidized by continuous burial of reduced biological products (principally organic matter and pyrite) ${ }^{13}$. This burial results from the failure of subsurface microbes to oxidize all of the 


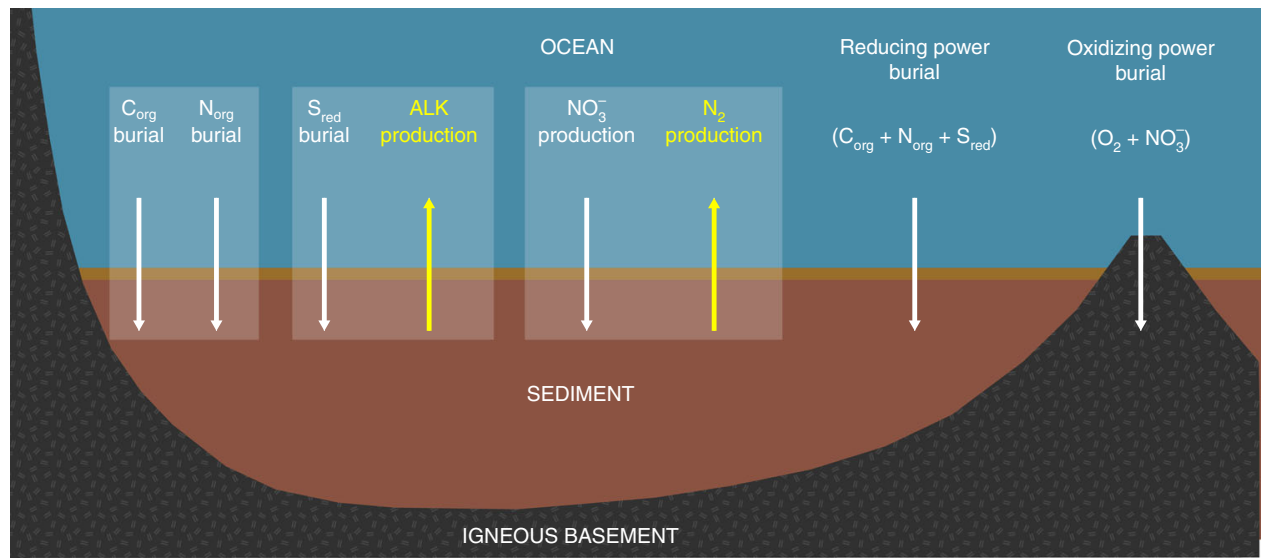

Fig. 4 Major net chemical fluxes due to microbial activities in subseafloor environments. Subseafloor microbial activities control burial fluxes of organic carbon $\left(\mathrm{C}_{\text {org }}\right.$ ), organic nitrogen $\left(\mathrm{N}_{\text {org }}\right)$, and reduced sulfur $\left(\mathrm{S}_{\text {red }}\right)$ (typically buried as iron sulfide), as well as production fluxes of alkalinity $(A L K)$ and $\mathrm{N}_{2}$. In doing so, they control the rate at which reducing power is buried. Microbes in igneous basement contribute to burial of oxidizing power (via reduction of $\mathrm{O}_{2}$ and $\mathrm{NO}_{3}{ }^{-}$)

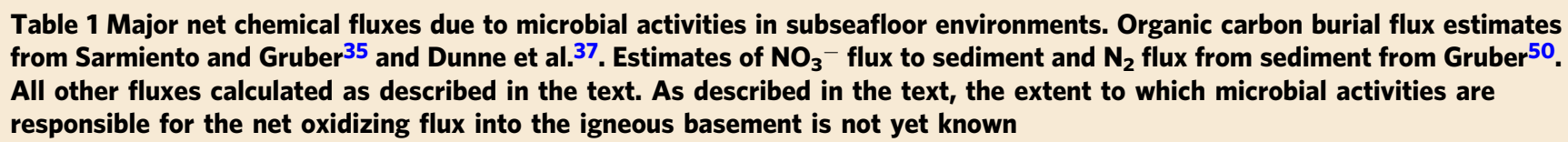

Net flux into igneous basement

$$
2.5 \pm 1.3 \times 10^{12} \mathrm{~mol} \text { electron }
$$
equivalents $\mathrm{yr}^{-1}$ ?

Net flux into igneous basement

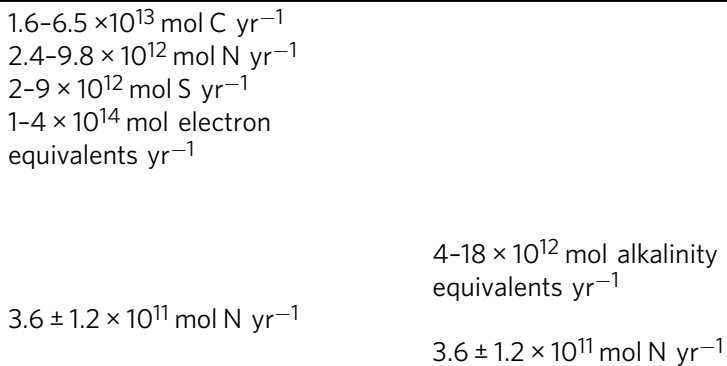


dissolved $\mathrm{NH}_{4}^{+}$, incorporated into mineral phases, or transformed to $\mathrm{N}_{2}$ by anaerobic processes ${ }^{44}$.

For this review, we quantify sedimentary redox fluxes in terms of the number of electrons transferred during reduction from the chemical species stable in contact with Earth's oxygenated atmosphere (e.g., $\mathrm{CO}_{2}, \mathrm{SO}_{4}{ }^{2-}, \mathrm{NO}_{3}{ }^{-}$) to the reduced chemical species that persist in subseafloor sediment (e.g., organic matter, $\mathrm{FeS}_{2}$ ) (Methods). We similarly quantify basement redox fluxes in terms of the electron numbers required to oxidize the reduced chemicals in basalt. Previous studies have presented redox fluxes in terms of $\mathrm{O}_{2}$ equivalents ${ }^{47}$ or $\mathrm{H}_{2}$ equivalents; ${ }^{13}$ one $\mathrm{O}_{2}$ equivalent corresponds to four electron equivalents and one $\mathrm{H}_{2}$ equivalent corresponds to two electron equivalents.

The total electron-equivalent burial rate in marine sediment, including reduced $\mathrm{C}, \mathrm{N}$ and $\mathrm{S}$, is $1 \times 10^{14}$ to $4 \times 10^{14}$ moles $\mathrm{e}^{-}$ $\mathrm{yr}^{-1}$ (Table 1). The marine sedimentary organic carbon burial rate of $1.6 \times 10^{13}$ to $6.5 \times 10^{13}$ moles $C \mathrm{yr}^{-1} 61,63$ equals $6.4 \times 10^{13}$ to $2.6 \times 10^{14}$ moles $\mathrm{e}^{-} \mathrm{yr}^{-1}$. Assuming an $\mathrm{N} / \mathrm{C}$ ratio equal to typical marine organic matter $(0.15)^{64}$, the marine sedimentary organic nitrogen burial rate is $2.4 \times 10^{12}$ to $9.8 \times 10^{12}$ moles $\mathrm{N}$ $\mathrm{yr}^{-1}$ (Table 1). Electron-equivalent burial as organic nitrogen $\left(1.9 \times 10^{13}\right.$ to $7.8 \times 10^{13}$ moles $\left.\mathrm{e}^{-} \mathrm{yr}^{-1}\right)$ is $\sim 1 / 3$ the rate of electron-equivalent burial as organic carbon.

Marine sedimentary communities also modulate redox pathways by transferring electrons from one buried chemical species to another, most notably by transferring electrons from organic matter to iron and sulfur, leading to $\mathrm{FeS}_{2}$ formation. In this case, reducing equivalents (electron equivalents) that were originally buried with organic matter continue to be buried with the sulfur and iron to which they were transferred. This transfer of electrons is significant. Given an average burial ratio of organic carbon to reduced sulfur in marine sediment $(7.5 \text { mole } \mathrm{C} / \text { mole S })^{65}$ and the organic burial rates mentioned above, the rate of reduced sulfur burial, principally as $\mathrm{FeS}_{2}$, is $2 \times 10^{12}$ to $9 \times 10^{12}$ moles $\mathrm{S} \mathrm{yr}^{-1}$ (Table 1). The burial rate of electron equivalents as reduced sulfur $\left(1.4 \times 10^{13}\right.$ to $6.3 \times 10^{13}$ moles $\left.\mathrm{e}^{-} \mathrm{yr}^{-1}\right)$ is approximately $1 / 4$ the rate of electron-equivalent burial as organic carbon and slightly lower than the rate of electron-equivalent burial as organic nitrogen.

Oxidation of the fractured igneous basement that underlies the sediment also plays a role in global redox cycling, by reducing the oxidation state of the ocean and atmosphere ${ }^{47}$. As seawater hydrothermally circulates through this aquifer, electron acceptors from the ocean, principally $\mathrm{O}_{2}$ and $\mathrm{NO}_{3}{ }^{-}$, oxidize reduced elements, principally iron and sulfur, in igneous minerals ${ }^{18}$. This circulation introduces electron acceptors to the upper crust throughout much of the ocean; dissolved $\mathrm{O}_{2}$ and $\mathrm{NO}_{3}{ }^{-}$is present in Eocene and Miocene basalt of the eastern Pacific ${ }^{21}$, Pleistocene to Cretaceous basalt of the central South Pacific ${ }^{16}$, and Miocene basalt of the North Atlantic ${ }^{66}$. The resulting oxidation of $1.7 \pm 1.2 \times 10^{12}$ moles $\mathrm{Fe}^{-1}$ and $1.1 \pm 0.7 \times 10^{11}$ moles $S \mathrm{yr}^{-1} 18$ reduces the ocean and atmosphere by $2.5 \pm 1.3 \times 10^{12}$ moles $\mathrm{e}^{-} \mathrm{yr}^{-1}$ (Table 1 ). The extent to which microbial respiration drives this oxidation is unknown, because dissolved $\mathrm{O}_{2}$ and $\mathrm{NO}_{3}{ }^{-}$abiologically oxidize reduced iron and sulfur ${ }^{67}$.

Multiple lines of evidence suggest that microbes harvest at least some of the energy from the mineral-oxidation reactions in the igneous basement. Microbial communities are routinely sampled from the basement aquifer ${ }^{3,36}$, members of these communities readily colonize fresh mineral surfaces ${ }^{68,69}$, and chemical data indicate that microbes play a role in late stages of rock alteration within the aquifer (e.g., $\mathrm{SO}_{4}{ }^{2-}$ reduction, methanogenesis) ${ }^{4,5}$. However, the extent to which subseafloor communities utilize the energy from these reactions is unknown. More importantly for this review, the net effect of that harvest on the global redox cycle is also unknown. For example, it is not yet clear if microbial communities enhance the total rate of basement oxidation by increasing the extent to which these reactions penetrate into the rock.

Impact on the global sulfur cycle. As the primary sink of sulfur from the ocean ${ }^{48}$ and a major source of alkalinity to the ocean ${ }^{11}$, $\mathrm{SO}_{4}^{2-}$ reduction coupled to $\mathrm{FeS}_{2}$ precipitation in marine sediment directly affects ocean chemistry and indirectly affects atmospheric chemistry and climate. Sulfate is the dominant electron acceptor in the anoxic sediment that blankets $\sim 60 \%$ of the seafloor. However, only a fraction of the sulfur reduced globally in marine sediment is precipitated as $\mathrm{FeS}_{2}$. Sulfur is reduced at the shallowest depths and highest rates in coastal environments, where up to $95 \%$ of the resulting sulfide diffuses upward and is re-oxidized ${ }^{70}$. In open-ocean environments, such as the equatorial Pacific, $\mathrm{SO}_{4}{ }^{2-}$ is reduced at greater sediment depths and iron concentration is great enough that $~ 100 \%$ of the reduced sulfur precipitates as $\mathrm{FeS}_{2}^{71}$.

The natural (pre-anthropogenic) flux of sulfur to the ocean is almost entirely via rivers. A recent estimate of this flux is $\sim 2 \times 10^{12}$ moles $\mathrm{S} \mathrm{yr}^{-1} 48$. This estimate ignores rapid cycling of sulfur between the ocean and the immediately overlying atmosphere. It also ignores rapid microbial cycling of sulfur reduction and re-oxidation in shallow marine sediment and the water column of oxygen-minimum zones. Again ignoring these rapid cycles, the flux of sulfur from the ocean is almost entirely via metal sulfide precipitation (primarily $\mathrm{FeS}_{2}$ in marine sediment $)^{13,48}$. As discussed above, we estimate the rate of reduced sulfur burial in marine sediment to be $2 \times 10^{12}$ to $9 \times 10^{12}$ moles $\mathrm{yr}^{-1}$ (Table 1).

Impact on alkalinity and atmospheric $\mathrm{CO}_{2}$. Precipitation of metal sulfide following $\mathrm{SO}_{4}{ }^{2-}$ reduction removes the anionic charge of $\mathrm{SO}_{4}{ }^{2-}$ from the ocean. This charge is balanced by production of alkalinity ${ }^{11}$ (alkalinity is equal to the sum of positive charge equivalents minus the equivalents of negative charge from the conjugate bases of strong acids $\left[\mathrm{Cl}^{-}\right.$and $\left.\left.\mathrm{SO}_{4}{ }^{2-}\right]\right)^{49}$. Consequently, precipitation in marine sediment of $2 \times 10^{12}$ to $9 \times 10^{12}$ moles reduced S yr ${ }^{-1}$ generates $4 \times 10^{12}$ to $1.8 \times 10^{13}$ moles of alkalinity equivalent $\mathrm{yr}^{-1}$ (Table 1). Given these estimates and a riverine primary alkalinity flux to the ocean of $1.3 \times 10^{13}$ mole equivalents $\mathrm{yr}^{-172}$, microbially induced precipitation of sedimentary $\mathrm{FeS}_{2}$ generates $24-58 \%$ of the annual primary alkalinity flux to the ocean. $\mathrm{CO}_{2}$ partial pressure $\left(p_{\mathrm{CO} 2}\right)$ is highly sensitive to the value of alkalinity; for present-day ocean chemistry, a $25 \%$ increase in alkalinity will decrease atmospheric $p_{\mathrm{CO} 2}$ by more than an order of magnitude (Methods).

Impact on the global nitrogen cycle. Ongoing burial of organic nitrogen is the primary sink of nitrogen from the atmosphere and ocean. Furthermore, microbial $\mathrm{NO}_{3}{ }^{-}$reduction (denitrification) linked to organic matter oxidation in marine sediment is the principal sink of fixed nitrogen from the ocean; the rate of sedimentary $\mathrm{NO}_{3}{ }^{-}$reduction is about a factor of two greater than the rate of denitrification in the water column and an order of magnitude larger than the rate of organic nitrogen burial ${ }^{50}$. In the absence of sedimentary denitrification, most marine ecosystems would not be nitrogen-limited. Most of this denitrification occurs in coast and shelf sediment, where the flux of organic matter to the seafloor is highest.

Impact on geological resources. Subseafloor microbial activities also play significant roles in creating and destroying resources of economic interest. The importance of subseafloor microbial 
activities is most fully delineated for destruction of subseafloor hydrocarbon resources ${ }^{51}$. More than $90 \%$ of the methane produced in marine sediment is consumed by anaerobic communities within the sediment ${ }^{73}$. Biodegradation is also extensive in relatively cool $\left(50^{\circ} \mathrm{C}\right)$ marine oil reservoirs, which have typically lost up to $\sim 50 \%$ of their mass of $\mathrm{C}_{6+}$ hydrocarbons ${ }^{51}$. Biodegradation decreases greatly as a function of reservoir temperature. Evidence of oil biodegradation is generally absent from reservoirs warmer than $80^{\circ} \mathrm{C}$, suggesting that the thermal limit to life in the reservoirs is close to that temperature ${ }^{51}$. Although microbial roles are less thoroughly studied for production and destruction of other economic resources, rates and subsurface locations of organic oxidation, sulfate reduction and methane production are known to play central roles in precipitating sedimentary deposits of phosphate ${ }^{52}$, barite ${ }^{55}$, dolomite ${ }^{53,54}$, and gas hydrates. Microbial activities may also play central roles in formation of marine metal deposits, including hydrothermal sulfides ${ }^{74}$.

The limits of subseafloor activity. Since active subseafloor communities are present throughout the world ocean, a paramount biogeochemical mystery has been the failure of those communities to completely consume the electron donors present in subseafloor environments. Even in oxic marine sediment, traces of organic matter may survive for 100 Myrs or more ${ }^{16}$. Reduced iron and reduced sulfur persist in subseafloor basalt for more than $100 \mathrm{Myrs}^{18}$. This failure plays a significant role in the redox evolution of Earth's atmosphere and ocean, because, as described above, sequestration of organic matter in marine sediment is a principal sink for reducing power from the surface world. Furthermore, failure of microbial communities to oxidize all of the iron and sulfur in the subseafloor igneous aquifer leaves oxidizing power in the ocean that might have otherwise been lost to mineral oxidation. The failure to consume all of the buried organic matter also decreases the influence of subseafloor respiration on global cycles of sulfur, nitrogen and alkalinity. The persistence of organic matter in marine sediment is also crucial for thermogenic formation of major hydrocarbon resources, because oil and gas cannot form in the absence of their feedstock.

Not all sedimentary organic matter is consumed. Organic oxidation rate is generally highest at the seafloor and decreases with sediment depth, declining rapidly near the seafloor and increasingly slowly with greater distance from the seafloor. This relationship is typically modeled as a power-law function ${ }^{17,75,76}$. The basic reaction series can be simplified as follows:

$$
\begin{array}{r}
6 \mathrm{CH}_{2} \mathrm{O}_{\text {POM }}--->\left(\mathrm{CH}_{2} \mathrm{O}\right)_{6 \text { (dissolved) }}-->2\left(\mathrm{CH}_{2} \mathrm{O}\right)_{3} \\
+3 \mathrm{SO}_{4}^{2-}-->6 \mathrm{CO}_{2}+3 \mathrm{H}_{2} \mathrm{~S}
\end{array}
$$

Standard models of organic persistence in marine sediment assume that the first step is the rate-limiting step ${ }^{75}$. However, if organisms are operating at their minimum harvestable reaction affinity ${ }^{77}$, catabolic reactions cannot proceed faster than reactants appear or reaction products disappear at the reaction location ${ }^{78}$. In this case, the rate-limiting step may occur later in the reaction series, such as the final respiration step of the above sequence, which will be limited by the rates at which $\mathrm{SO}_{4}{ }^{2-}$ is introduced and the rate(s) at which $\mathrm{CO}_{2}$ and $\mathrm{H}_{2} \mathrm{~S}$ are removed (Box 2).

This dependence of organic oxidation rate on chemical fluxes and minimum reaction affinity will naturally lead to the typical depth-dependence of organic oxidation rate (Box 2). Because the time required for chemical diffusion is proportional to the square of diffusive distance ${ }^{79}$, where advection is insignificant (below the depth of bio-irrigation), organic oxidation rate must decline exponentially with distance from sources of catabolic reactants and sinks of catabolic products (Box 2). Where electron acceptors and catabolic products respectively diffuse from and to the ocean above, the rate of organic oxidation will decline exponentially with depth beneath the seafloor.

Most quantitative models of the decline in bulk organic oxidation rate with sediment depth assume that organic persistence results from organic molecular structure, with selective preservation of the least reactive (most carbon-rich) compound ${ }^{75,76}$. These models are variations on Berner's 1964 G Model, which assumed organic oxidation rate to be proportional to organic matter concentration ${ }^{76}$. More recent models assume that bulk organic oxidation rate declines with sediment depth and age because increasingly recalcitrant pools of organic matter are successively depleted ${ }^{17}$. This assumption is consistent with laboratory experiments that show sequential utilization of different sedimentary organic carbon pools by aerobic heterotrophs $s^{80}$. Despite this consistency, reliance on relative degradability to explain organic oxidation rates is problematic for the following reasons. First, the molecular composition of these organic pools is never identified by studies that assume them to model organic oxidation rates ${ }^{17,76}$. Second, the degradability of an organic-matter pool, such as kerogen (the fraction of organic matter insoluble to organic solvents) in deeply buried sediment, is not inherent to the organic molecules that compose that pool, but depends on the environment in which the organic pool is present ${ }^{81}$. For example, 365-million-year-old organic matter is quickly degraded by microbes when exposed by erosion ${ }^{82}$. Third, preferential degradation or persistence of different classes of organic compounds may be better considered as a function of community metabolic capabilities than as an intrinsic property of organic molecules ${ }^{83}$. Fourth, preferential persistence of the most carbon-rich compounds is difficult to reconcile with preservation of relatively low $\mathrm{C} / \mathrm{N}$ ratios for tens of $\mathrm{Myrs}^{84,85}$, and with subseafloor respiration of $\mathrm{C} / \mathrm{N}$ ratios close to the average marine (Redfield) value for tens of Myrs ${ }^{16,29,86}$.

Other studies have proposed that organic matter persists because it is adsorbed to mineral grain $8^{85,87,88}$. This hypothesis is consistent with a generally close association between high bulk organic concentrations and abundance of fine-grained minerals ${ }^{65}$. However, reliance on organic adsorption to minerals as the primary explanation of organic persistence in marine sediment is difficult to sustain for the following reasons. First, it is difficult to reconcile the molecular integrity of some compounds, such as certain fatty acids and pigments, with the solubilization that must precede adsorption ${ }^{89}$. Second, discontinuous distribution of organic matter renders binding to mineral grains an insufficient explanation of organic persistence in continental-margin sediment ${ }^{65,90}$. Third, much of the adsorption to minerals is easily reversed and ultimately cannot preserve organic matter ${ }^{91}$.

These different explanations have fundamentally different implications for the relationship between organic oxidation rates and organic-matter persistence in deep old sediment. To the extent that organic oxidation rate depends on minimum reaction affinity and diffusion rates of dissolved catabolic reactants and products (Box 2), organic matter can persist simply because oxidation rate declines with sediment depth. In contrast, selective-preservation hypotheses assume that organic oxidation rate declines because residual organic molecules are chemically recalcitrant. Finally, the mineral adsorption hypothesis could be used to predict that organic oxidation rate declines because residual organic matter is strongly adsorbed to minerals.

Demonstration of increased organic recalcitrance or increased mineral adsorption with sediment age is necessary to respectively support the hypotheses that organic recalcitrance or mineral adsorption drives the decrease in organic oxidation rate with increasing sediment depth and age. However, neither test is sufficient to prove either hypothesis, because organic recalcitrance 


\section{Box 2 | Dependence of organic oxidation rate on diffusion timescale}

If the affinity of a catabolic reaction drops below the minimum value necessary to sustain biological energy conservation (Box 1), the energy of reaction is not biologically harvestable until the affinity of the reaction rises again. In short, the rate of catabolic activity is limited by the flux of bioavailable energy ${ }^{78}$. As the reaction proceeds, its affinity decreases. When it drops below the minimum value, energy is no longer conserved and the reaction stops until more reactant is introduced or reaction product is removed.

This relationship between the affinity of a reaction and the rate of that reaction is exemplified by chemostats, in which growth rate depends on the rate that reactants are added and products are removed. However, in a chemostat, reactants (e.g., $\mathrm{O}_{2}, \mathrm{NO}_{3}{ }^{-}, \mathrm{SO}_{4}{ }^{2-}$ ) are typically added by fluid inflow and reaction products [e.g., DIC] are removed by fluid outflow. In contrast, in most marine sediment, catabolic reactants are added and catabolic products are removed via diffusion. Because the timescale of diffusion is proportional to diffusive distance squared ${ }^{79}$, the rates of reactant introduction and product removal via diffusion decrease strongly with distance to the reactant source and distance to the product sink. In effect, increasing sediment thickness drives subseafloor ecosystems toward being closed systems ${ }^{40}$.

In other words, the rate of catabolic activity is expected to decrease with distance from where a reactant is introduced or a product is lost, due to the decreasing rate of diffusive transport, even if the lability and concentration of organic matter are constant throughout the sediment column (Methods). The effect of diffusive distance is small for reactants produced in situ ${ }^{38}$, such as radiolytic $\mathrm{H}_{2}$, and products removed in situ, such as sulfide precipitated in FeS 2 at the location of sulfide production. However, this effect can be significant for reactants and products that diffuse to or from elsewhere in the sediment column (e.g., for $\mathrm{O}_{2}, \mathrm{NO}_{3}{ }^{-}$or $\mathrm{SO}_{4}{ }^{2-}$ that diffuses into the sediment from the overlying ocean, and for DIC that diffuses from the sediment into the ocean). We illustrate this effect with $\mathrm{DIC}$ production by sulfate-reducing oxidation of a carbohydrate $\left(\mathrm{CH}_{2} \mathrm{O}+0.5 \mathrm{SO}_{4}^{2-}=>\mathrm{HCO}_{3}{ }^{-}+0.5 \mathrm{HS}\right)$. We focus on $\mathrm{HCO}_{3}{ }^{-}$because DIC is predominantly $\mathrm{HCO}_{3}{ }^{-}$in marine sediment. For simplicity, this example assumes that concentrations of $\mathrm{HS}^{-}, \mathrm{CH}_{2} \mathrm{O}$ and $\mathrm{SO}_{4}{ }^{2-}$ are constant or proportionally change to a much lesser extent than $\mathrm{HCO}_{3}{ }^{-}$. Given this assumption and reaction affinity at the minimum biologically harvestable value, reaction rate directly depends on the net rate of DIC diffusion at each depth. Expansion of this model to include catabolic reactants, additional reaction products and/or additional reactions (e.g., organic solubilization and fermentation) would complicate the model, but lead to a similar result.

In this model, the $\mathrm{HCO}_{3}{ }^{-}$production rate at distance $z$ from the top of a sediment column is given by

$P(z)=P_{\max }\left(1-c(z) / c_{A-\min }\right)(2)$

where $P_{\max }$ is the maximum $\mathrm{HCO}_{3}-$ production rate (which occurs at the top of the sediment column), $c(z)$ is the $\mathrm{HCO}_{3}-$ concentration at depth $z$, and $\mathrm{C}_{\mathrm{A}-\mathrm{min}}$ is the $\mathrm{HCO}_{3}-$ concentration above which $\mathrm{A}$ drops below $A_{\text {minimum }}$ and energy-yielding $\mathrm{HCO}_{3}$ - production stops. Balancing diffusive transport with reaction rate parameterized in this way leads to the expectation that catabolic reaction rate decreases exponentially with sediment depth.

This relationship between catabolic rate and diffusive distance is consistent with the generally observed strong and initially rapid decline in organic oxidation rate with sediment depth ${ }^{17}$. It is also consistent with the generally strong correlation between organic burial efficiency and sedimentation rate ${ }^{65,75}$. In the extreme case of fast-accumulating organic-rich sediment, sedimentary communities are buried faster than reactants (such as $\mathrm{O}_{2}, \mathrm{NO}_{3}{ }^{-}$ and $\mathrm{SO}_{4}{ }^{2-}$ from the overlying ocean) can diffuse to them and faster than terminal reaction products (such as DIC and $\mathrm{CH}_{4}$ ) can diffuse to a sink (such as the anaerobic methane-oxidizing zone or the seafloor). In this system, abundant and compositionally diverse organic matter may persist in deep sediment because reaction rates are too low to consume it.
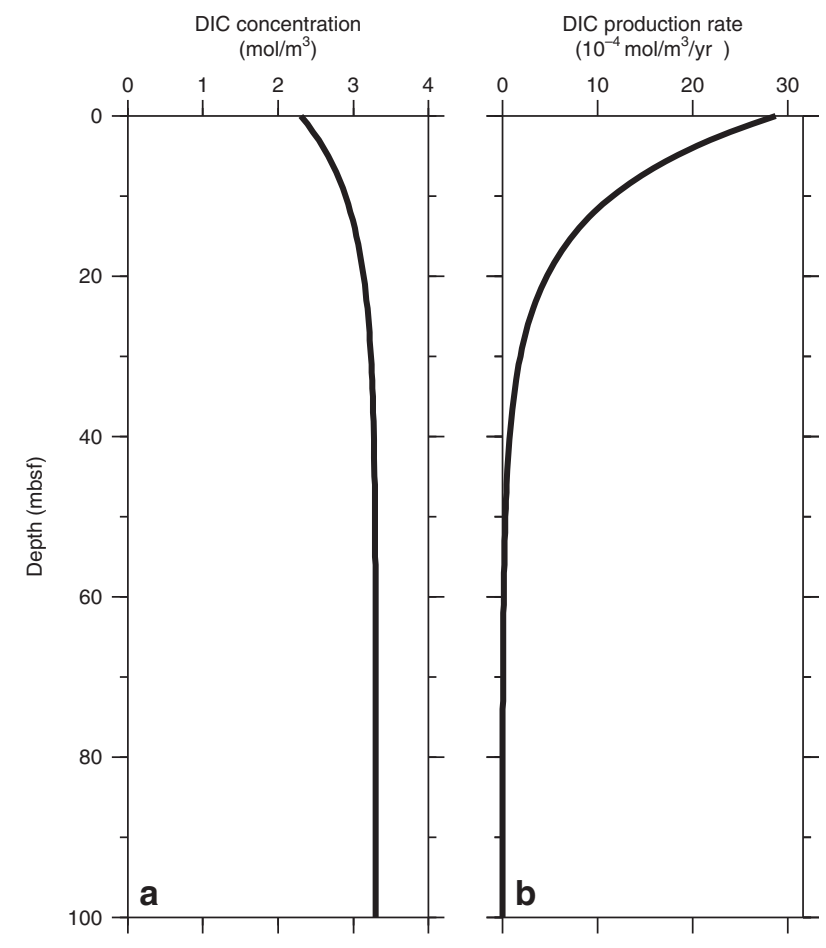

and/or mineral adsorption might increase with sediment age even if they do not drive the decrease in organic oxidation rate with sediment depth and age.

Persistence of electron donors in subseafloor sediment is not limited to solid-phase organic matter. For example, the turnover times of dissolved fatty acids in sulfate-reducing subseafloor sedimentary ecosystems ranges from approximately tens to hundreds of years (Methods). These relatively long turnover times of dissolved electron donors are not explainable by chemical recalcitrance or adsorption to minerals. However, they are a natural consequence of microbial thermodynamics coupled to subseafloor timescales of chemical diffusion (Box 2). 
The causal relationship between organic oxidation rates and organic-matter persistence may differ from one marine sedimentary environment to another. Diffusion of chemical species may limit organic oxidation rates in fast-accumulating anoxic sediment, where organic oxidation reactions operate at minimum harvestable affinities of reaction. However, in sediment where electron acceptors are abundant and reaction products are scarce, organic persistence may result from mineral shielding or molecular inaccessibility of the organic matter. Such circumstances might apply in the slowly accumulating organic-poor oxic sediment that blankets much of the abyssal ocean ${ }^{16,85}$.

The igneous subseafloor is not fully oxidized. The factors that limit oxidation rates in the igneous subseafloor are rarely addressed explicitly. The permeability of un-fractured basalt is extremely low and rock alteration is closely associated with fractured surfaces ${ }^{92}$. Given these points, persistence of reduced iron and sulfur in subseafloor basalt can most simply be ascribed to physical inaccessibility of the reduced elements within the unfractured rock. This ascription is a variation on the diffusivetimescale explanation that we present for sedimentary organic oxidation above and in Box 2; however, in the igneous basement, permeability is so low that chemical diffusion of electron acceptors into un-fractured rock is extremely slow, even for submillimeter distances.

The persistence of dissolved organic matter (DOM) in the igneous aquifer is more enigmatic. DOM enters the aquifer with water from the overlying ocean ${ }^{6}$. Because DOM is in the water, not the rock, it is in contact with dissolved electron acceptors. Although some DOM is consumed within the aquifer, DOM is present along the entire flow path. In the cool oxygenated aquifer of North Pond (North Atlantic), DOM has radiocarbon model ages of several thousand years ${ }^{6}$. These model ages are significantly older than the residence time of water in the aquifer or the residence time of deep water in the North Atlantic, suggesting ongoing supply of aged organic matter to the deep ocean and the aquifer.

Microbial activities and the subseafloor limit to life. The preceding paragraphs and Box 2 focus on limits to subseafloor activity in environments where organisms are present and metabolically active. In subseafloor environments, fluxes of bioavailable energy may be too low to maintain community function under physical conditions that differ notably from physical limits to life in other environments. For example, the high-temperature limit to oil and gas bioalteration $\left(80-90^{\circ} \mathrm{C}\right)^{51}$ is considerably lower than the high-temperature limit to life in energy-rich and nutrient-rich autoclave conditions $\left(122^{\circ} \mathrm{C}\right)^{8}$. This difference illustrates that the high-temperature limit to life may vary from one environment to another as a function of bioavailable energy flux or nutrients ${ }^{9,51}$.

Factors other than temperature may also sterilize subseafloor systems. More precisely, changes in chemical conditions might sterilize subseafloor environments after multi-Myr intervals of selection for previous chemical conditions. For example, the oxic condition of abyssal clay sequences for tens of Myrs may drive obligate anaerobes in the clay to extinction, to be followed by local extinction of aerobes if sedimentation rates increase and dissolved $\mathrm{O}_{2}$ disappears from the clay.

Future directions. As indicated in the preceding sections, many key issues remain to be resolved. Global rates of subseafloor microbial activities and their consequences are only roughly quantified. For example, recent estimates of organic carbon burial in marine sediment differ by $\sim 4 \times^{61,63}$ and recent estimates of global $\mathrm{SO}_{4}{ }^{2-}$ reduction rate in marine sediment differ by $\sim 7.5 \times 93,94$. Our estimates of $\mathrm{FeS}_{2}$ precipitation rate, alkalinity production rate and organic nitrogen burial rate in marine sediment are based on estimates of organic carbon burial rate and also vary by $\sim 4 \times$. This lack of precision is exacerbated by incomplete understanding of microbial processes in the subseafloor. For example, the extent to which microbes participate in redox alteration of inorganic phases in subseafloor basalt and sediment remains to be determined. More precisely, the extent to which microbes harvest the energies of mineral-altering redox processes that can proceed abiologically is not known. Furthermore, the extent to which microbes actively enhance mineral alteration, e.g., by mining more deeply or more rapidly into minerals and/or rock than done by abiotic alteration, is also unknown.

The factors that limit rates of subseafloor catabolic activities are crucial to the operation of Earth's biogeochemical cycles but not fully understood. Consideration of reaction affinities and dissolved chemical transport suggests that diffusion rates of catabolic reactants and products play an important and previously under-recognized role in limiting subseafloor catabolic rates and, thereby, sustaining the persistence of electron donors in subseafloor environments.

The specific taxa responsible for individual activities are not known for most subseafloor environments ${ }^{46}$. The metabolic networks that sustain their communities for millions of years are largely unexplored. The nature and extent of communication between cells in subseafloor communities is unexamined. At the most fundamental biological level, the genomic properties and patterns of gene expression that enable lineages of subseafloor microbes to survive at extraordinarily low rates of activity for millions of years remain unknown ${ }^{28}$.

Better quantification of subseafloor microbial activity rates and their consequences will require integration and quantitative analysis of data from diverse studies. For example, more accurately quantifying global burial rates of organic carbon, organic nitrogen and sulfide in marine sediment will require synthesis of geochemical data from shallow and deep sediment of coastal environments, continental shelves and the open ocean. And precise quantification of sulfide burial's effect on ocean alkalinity and atmospheric chemistry will require quantification of both sulfide burial and sulfate flux to the ocean.

Deeper understanding of subseafloor activities and their consequences will require Earth and life scientists to deliberately integrate techniques from diverse fields (e.g., molecular biology, aqueous geochemistry, sedimentology, petrology and mineralogy) to test key hypotheses. For example, fuller understanding of how dissolved chemical transport and reaction affinities limit rates of subseafloor activities - and ultimately control global biogeochemical fluxes - will require integrated study of in situ abilities to undertake specific catabolic reactions, in situ reaction rates, and in situ energies of reaction.

Hypothesis-driven laboratory experiments and direct study of natural communities will both be crucial to advance understanding of the physiological features, metabolic strategies, and genomic properties that enable lineages of subseafloor microbes to persist at extraordinarily low rates of activity for millions of years. Laboratory experiments are necessary to elucidate the features and strategies that enable microbes to thrive or survive under specific subseafloor conditions, at least on laboratory timescales, and the genes that code for those features and strategies. Direct studies of natural subseafloor communities are needed to delineate the conditions in which they live, to characterize microbial interactions in subseafloor communities, and to identify features and strategies that enable microbial 
lineages and communities to thrive or survive under subseafloor conditions for many millions of years.

With both laboratory experiments and natural-sample studies, a broad range of analytical approaches is crucial to understand the organisms and communities. Genomic studies are necessary to know what capabilities are available. Transcriptomic studies are needed to understand which capabilities are expressed. Biogeochemical studies are required to determine in situ reaction rates, in situ energies of reaction, and consequences of microbial activities. Exacting studies of organic composition and mineral composition are necessary to identify the substrates available to subseafloor organisms and the consequences of microbial activities. Natural-community studies often benefit from explicitly placing them in a temporal context, e.g., by repeatedly sampling a subseafloor flow path over time ${ }^{37}$, by sampling crust of very different ages, or by treating data from younger samples in the same sediment column as potentially representative of earlier stages in the history of a subseafloor community ${ }^{29,95,96}$ or habitat. Such temporal context is crucial for understanding how subseafloor communities are assembled. It is also critical for understanding how their biogeochemical roles and consequences vary throughout the subseafloor in space and time.

Individual studies need not integrate across many categories of study. Appropriate laboratory experiments can bring great value whether they are tied to specific field sampling programs or not. Similarly, well-posed natural-sample studies can effectively address key problems (e.g., quantification of specific biogeochemical fluxes or identification of globally consistent genomic and/or transcriptomic patterns) without close integration to other categories of natural-sample study or to laboratory experiments. Ultimately, however, each category of study derives greater strength by integration with one or more of the other categories. For example, laboratory studies inform the understanding of data from subseafloor samples, and subseafloor data inform the hypotheses that drive the laboratory experiments. Understanding of natural subseafloor communities and their consequences also benefits from synthesizing results of different approaches to natural samples. For example, biogeochemical results might explain why a specific capability that is present is not expressed, and genomic studies might explain why a reaction that is energetically feasible does not occur.

As shown by these examples, close integration of biological, chemical and physical approaches will ultimately be necessary to further advance understanding of subseafloor life and its biogeochemical consequences. This integration will require both Earth and life scientists to begin thinking of many geological and geochemical features (such as organic recalcitrance and rates of subseafloor redox processes) as ecosystem properties, rather than a priori environmental features.

\section{Methods}

Calculation of habitable basement volume. The total volume (rock + water) of submarine igneous basement cooler than $122^{\circ} \mathrm{C}$ is $3.0 \times 10^{8} \mathrm{~km}^{3}$. We calculated this total volume using the method of Heberling et al. ${ }^{97}$; however, instead of globally averaged theoretical and observed heat flow values ${ }^{98}$ and constant sedimentation rate of $3 \mathrm{~m} \mathrm{Myr}^{-1}$, we used global grids of heat flow ${ }^{99}$ and sediment thickness ${ }^{100}$ to calculate global maps of depth to the $122^{\circ} \mathrm{C}$ isotherm with a grid resolution of $0.1 \times 0.1$ degrees. We then spatially integrated these depths to calculate a global volume.

Assuming $10 \%$ in upper $500 \mathrm{~m}$ of basement and a linear decrease in porosity to zero at $1000 \mathrm{~m}$ into basement ${ }^{101}$, habitable pore space in the basement is $2.2 \times 10^{7} \mathrm{~km}^{3}$ (about $2 \%$ of ocean volume).

Determination of dissolved $\mathbf{O}_{2}$ and $\mathbf{S O}_{4}{ }^{2-}$ distributions. We used interstitial water concentrations of dissolved $\mathrm{O}_{2}$ and $\mathrm{SO}_{4}{ }^{2-}$ from ODP and IODP drill sites ${ }^{102}$ and a two-step approach to create the global map of electron acceptor distributions in sediment (Fig. 1). The first step was to plot the chemical species as a function of sediment depth and note whether their concentration goes to zero within the

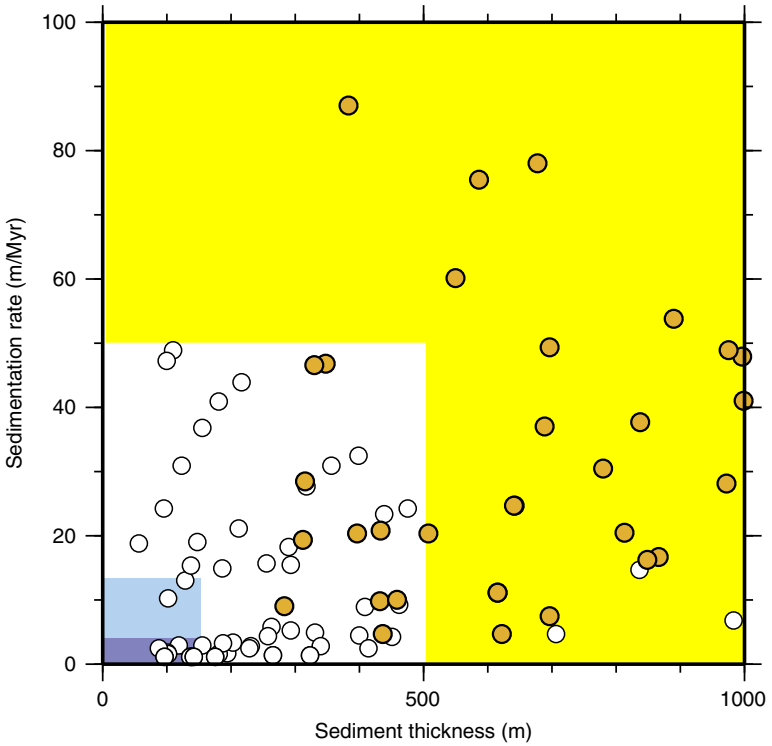

Fig. 5 Plot of sediment thickness and sedimentation rate at ODP and IODP sites. Only sites where dissolved $\mathrm{SO}_{4}{ }^{2-}$ has been measured in sedimentary porewater are shown. Orange dots indicate sites where $\mathrm{SO}_{4}{ }^{2-}$

concentrations go to zero within the upper $500 \mathrm{~m}$ of sediment. White dots indicate sites where $\mathrm{SO}_{4}{ }^{2-}$ is present from seafloor to basement. The yellow, dark blue and light blue fields identify the sediment thickness and sedimentation rate boundaries used to generate Fig. 1. The blue fields are based on previous results for dissolved $\mathrm{O}_{2}$ reported by D'Hondt et al. ${ }^{16}$.

Dissolved $\mathrm{O}_{2}$ may or may not be present throughout the sediment at sites marked by white dots in the blue fields; no $\mathrm{O}_{2}$ measurements were made at these sites. White dots in the yellow areas include sites where flow introduces $\mathrm{SO}_{4}{ }^{2-}$ through rubble or from beneath the seafloor and sites where $\mathrm{SO}_{4}{ }^{2-}$ diffuses upward from underlying brine. Orange dots in the white field generally mark sites where dissolved chemical concentrations are not at diffusive steady state (e.g., because sedimentation rate has been unusually high in the recent geologic past)

sediment or is non-zero all the way to basement. Of 380 ODP and IODP drill sites with $\mathrm{SO}_{4}{ }^{2-}$ data, $\mathrm{SO}_{4}{ }^{2-}$ concentrations go to zero within the sediment at 150 sites, 70 sites had non-zero $\mathrm{SO}_{4}{ }^{2-}$ concentrations from seafloor to basement, and 160 sites were undetermined because the sites were not drilled to basement or $\mathrm{SO}_{4}{ }^{2-}$ measurements were stopped at depths far above basement. The dissolved $\mathrm{O}_{2}$ results were previously reported in D'Hondt et al. $(2015)^{16}$.

The second step identified relationships between the presence and absence of the various chemical species as a function of sedimentation rate and total sediment thickness. This method was previously used for $\mathrm{O}_{2}$ in sediment; ${ }^{16}$ we extended it to include the $\mathrm{SO}_{4}{ }^{2-}$ data (Fig. 5). Our results indicate that $\mathrm{SO}_{4}{ }^{2-}$ goes to zero in the sediment column when sediment thickness exceeds about $500 \mathrm{~m}$ or sedimentation rate exceeds $35 \mathrm{~m} \mathrm{Myr}^{-1}$. In comparison, dissolved $\mathrm{O}_{2}$ concentrations go to zero in the sediment where sediment thickness exceeds about $150 \mathrm{~m}$ or sedimentation rate exceeds $15 \mathrm{~m} \mathrm{Myr}^{-1}$. These 'boundaries' for persistence or absence of $\mathrm{SO}_{4}^{2-}$ to igneous basement were combined with similar boundaries for dissolved $\mathrm{O}_{2}$ (e.g., D'Hondt et al., 2015) to generate Fig. 1 from global sediment-thickness maps ${ }^{100}$ and depth-averaged sedimentation rates. The depth-averaged sedimentation rates were derived from the sediment thickness maps and global maps of ocean basement age ${ }^{103}$.

Reaction-rate calculations. To quantify net rates of $\mathrm{O}_{2}$ reduction (IODP Site $\mathrm{U} 1370$ ) and $\mathrm{SO}_{4}{ }^{2-}$ reduction (ODP Sites 1226 and 984) from dissolved chemical data (Fig. 2a-c), we used a modified version of the Matlab-based numerical procedures of Wang et al. ${ }^{71}$. We modified the approach of Wang et al. by using an Akima spline, instead of a 5-point running mean, in order to generate a best-fit line to the chemical concentration data. We determined standard deviations through use of a Monte Carlo simulation $(n=50)$. For these calculations, diffusivities are from Schulz ${ }^{104}$, corrected for in situ temperature at Sites 1226 and U1370 (temperature was assumed constant at Site 984, where in situ temperature was not measured). Porosities and in situ temperature data are from shipboard measurements of the respective drilling expeditions ${ }^{105-107}$ (available at http://sedis.iodp. 
org). Sedimentation rates are from the shipboard age models generated for each drill site ${ }^{105-107}$

Calculation of electron-equivalent burial rates. We calculate electron-equivalent burial rates by multiplying the difference between the dominant oxidation state of the chemical element (C, N or S) at Earth's surface and its oxidation state in marine sediment. The dominant surface-Earth oxidation states for $\mathrm{C}, \mathrm{N}$, and $\mathrm{S}$ are IV, 0 and VI, respectively. The oxidation states in marine sediment are taken as 0 , -III and $-\mathrm{I}$ for organic $\mathrm{C}$, organic $\mathrm{N}$ and $\mathrm{S}$ in $\mathrm{FeS}_{2}$.

Calculation of alkalinity effect on $\mathrm{CO}_{2}$ partial pressure. Increasing alkalinity from present ocean values will cause net conversion of dissolved $\mathrm{CO}_{2}$ to predominantly $\mathrm{HCO}_{3}{ }^{-}$and to a lesser extent $\mathrm{CO}_{3}{ }^{2-}$ (dissolved $\mathrm{CO}_{2}=\mathrm{H}_{2} \mathrm{CO}_{3}+$ $\mathrm{CO}_{2}$ ). We calculated the exact change in equilibrium $\mathrm{CO}_{2}$ partial pressure for a given change in alkalinity using the thermodynamic constants for the aqueous $\mathrm{CO}_{2}$ system $^{49}$.

Dependence of organic degradation on diffusive distance. Our idealized model of the depth dependence of organic degradation rate assumes that the rate of a catabolic reaction sequence (i.e., production of a sugar monomer from particulate organic matter, followed by fermentation and respiration), occurs at or near steady state at a given sediment depth and that the energy $(-\Delta G)$ yielded by each biologically conserved reaction (fermentation or respiration) must equal or exceed the minimum amount that can be biologically conserved $\left(\Delta G_{\text {minimum }}\right)^{77,108,109}$. That is, the affinity $(A=-\Delta G)$ for each catabolic reaction must equal or exceed the biological minimum affinity $\left(A_{\text {minimum }}\right)$. This assumption is supported by observations of in situ energies of reactions in marine sediment ${ }^{44,77,110,111}$. Here, we use $\mathrm{SO}_{4}{ }^{2-}$ reduction as an example. In this approach, the catabolic production rate of DIC (of which $\mathrm{HCO}_{3}{ }^{-}$is the major species) depends on the $\mathrm{HCO}_{3}{ }^{-}$concentration, $1-c / c_{A-\min }$, to keep $A \geq A_{\text {minimum }}$, where $c_{A-\min }$ is the $\mathrm{HCO}_{3}{ }^{-}$concentration above which $A$ drops below $A_{\text {minimum }}$ and the reaction sequence does not proceed.

This dependence of rate on metabolite concentrations was previously applied by Boudart $(1978)^{112}$ to generic reaction sequences and adopted by Jin and Bethke $(2009)^{78}$, and Dale et al. $(2008)^{113}$. We extend this approach by explicitly identifying the effect of diffusive distance on reaction rate, via its effect on metabolite concentrations. We choose $\mathrm{HCO}_{3}{ }^{-}$for this demonstration because, in sulfatereducing sediment where sulfide is scavenged by iron, $\mathrm{HCO}_{3}{ }^{-}$exhibits the largest relative change in concentration.

$P(z)$, the production of DIC at depth $z$ is then given by

$$
\left.P(z)=P_{\max }(1-c(z)] / c_{A-\min }\right)
$$

where $c(z)$ is the $\mathrm{HCO}_{3}{ }^{-}$concentration at depth $z$, and $P_{\text {max }}$ is the rate when $c=0$ and the local mass balance is

$$
\begin{gathered}
\frac{\partial c(z, t)}{\partial t}=0=D \frac{\partial^{2} c(z, t)}{\partial z^{2}}+P(z) \\
0=D \frac{\partial^{2} c(z, t)}{\partial z^{2}}+P_{\max }\left(1-\frac{c(z)}{c(z)_{A-\min }}\right)
\end{gathered}
$$

where $D$ is the $\mathrm{HCO}_{3}{ }^{-}$diffusion constant. A solution to Eq. (3) is

$$
c(z)=\left(c(z=0)-c_{A-\min }\right) *\left(\operatorname { e x p } \left(-P_{\max } /\left(D * c_{A-\min }\right)+c_{A-\min }\right.\right.
$$

and the depth-dependent metabolic rate is then

$$
P(z)=P_{\max } * \exp \left(\left(-P_{\max } /\left(D c_{A-\min }\right)^{0.5} z\right)\right)
$$

Where $P_{\max }=$ DIC production rate when $c_{D I C}=0$.

Turnover-time calculations. The turnover times of low-molecular-weight fatty acids are calculated as the concentration of lactate, acetate or formate divided by the rate of $\mathrm{SO}_{4}{ }^{2-}$ reduction corrected for stoichiometry (respectively 1.0, 0.67, and 0.5 times the rate of $\mathrm{SO}_{4}{ }^{2-}$ reduction for acetate, lactate, and formate) at IODP Site 1226, a site where $\mathrm{SO}_{4}{ }^{2-}$ is reduced but not entirely depleted. The different ratios to $\mathrm{SO}_{4}{ }^{2-}$ reduction are used to account for the different oxidation states and numbers of carbon atoms in each molecule, assuming the initial particulate organic carbon (POC) had oxidation state 0 . Because we do not know the fraction of total $\mathrm{SO}_{4}{ }^{2-}$ reduction rate that goes to oxidize each of these low-molecular-weight acids, we calculated a potential range of turnover times based on each one separately. At this site, concentrations of these lowmolecular-weight fatty acids are all in the range of $1 \mu \mathrm{M}^{111}$ and the subseafloor $\mathrm{SO}_{4}{ }^{2-}$ reduction rate declines from $3 \times 10^{-8}$ moles liter ${ }^{-1} \mathrm{yr}^{-1}$ to $\sim 0.2 \times 10^{-8}$ moles liter ${ }^{-1} \mathrm{yr}^{-1}$ with increasing depth below seafloor ${ }^{71}$. Given the relatively constant low-molecular-weight fatty acid concentrations, the decline in $\mathrm{SO}_{4}{ }^{2-}$ reduction rate leads to turnover times increasing from the low tens to low hundreds of years with increasing sediment depth.

\section{Data availability}

All data are previously published and accessible as identified in the cited sources.
Received: 21 September 2017 Accepted: 10 July 2019

Published online: 06 August 2019

\section{References}

1. Kallmeyer, J., Pockalny, R., Adhikari, R. R., Smith, D. C. \& D’Hondt, S. Global distribution of microbial abundance and biomass in subseafloor sediment. Proc. Natl Acad. Sci. USA 109, 16213-16216 (2012).

2. Whitman, W. B., Coleman, D. C. \& Wiebe, W. J. Prokaryotes: the unseen majority. Proc. Natl Acad. Sci. USA 95, 6578-6583 (1998).

3. Cowen, J. P. et al. Fluids from aging ocean crust that support microbial life. Science 299, 120-123 (2003)

4. Alt, J. C. et al. Hydrothermal alteration and microbial sulfate reduction in peridotite and gabbro exposed by detachment faulting at the Mid-Atlantic Ridge, $15^{\circ} 20^{\prime} \mathrm{N}$ (ODP Leg 209): A sulfur and oxygen isotope study. Geochem. Geophys. Geosyst. 8, 1-22 (2007).

5. Lever, M. A. et al. Evidence for microbial carbon and sulfur cycling in deeply buried ridge flank basalt. Science 339, 1305-1308 (2013).

6. Shah Walter, S. R. et al. Microbial decomposition of marine dissolved organic matter in cool oceanic crust. Nat. Geosci. 11, 334-339 (2018).

7. Fisk, M. R., Giovannoni, S. J. \& Thorseth, I. H. Alteration of oceanic volcanic glass: textural evidence of microbial activity. Science 281, 978-980 (1998)

8. Takai, K. et al. Cell proliferation at $122^{\circ} \mathrm{C}$ and isotopically heavy $\mathrm{CH}_{4}$ production by a hyperthermophilic methanogen under high-pressure cultivation. Proc. Natl Acad. Sci. USA 105, 10949-10954 (2008).

9. LaRowe, D. E., Burwicz, E., Arndt, S., Dale, A. W. \& Amend, J. P. Temperature and volume of global marine sediments. Geology 45, 275-278 (2017).

10. Eskins, B. W. \& Sharman, G. F. Volumes of the World's Oceans from ETOPO1 (NOAA National Geophysical Data Center, 2010).

11. D'Hondt, S., Rutherford, S. \& Spivack, A. J. Metabolic activity of subsurface life in deep-sea sediments. Science 295, 2067-2070 (2002).

12. Roy, H. et al. Aerobic microbial respiration in 86-million-year-old deep-sea red clay. Science 336, 922-925 (2012).

13. Kasting, J. F. What caused the rise of atmospheric $\mathrm{O}_{2}$ ? Chem. Geol. 362, 13-25 (2013).

14. Des Marais, D. J. Isotopic evolution of the biogeochemical carbon cycle during the Proterozoic Eon. Org. Geochem. 27, 185-193 (1997).

15. Johnson, B. \& Goldblatt, C. The nitrogen budget of Earth. Earth-Sci. Rev. 148, 150-173 (2015).

16. D'Hondt, S. et al. Presence of oxygen and aerobic communities from sea floor to basement in deep-sea sediments. Nat. Geosci. 8, 299-304 (2015).

17. Røy, H. Experimental assessment of community metabolism in the subsurface. in Microbial Life of the Deep Biosphere (eds. Kallmeyer, J., Wagner, D.) 303-317 (De Gruyter, 2014).

18. Bach, W. \& Edwards, K. J. Iron and sulfide oxidation within the basaltic ocean crust: Implications for chemolithoautotrophic microbial biomass production. Geochim. et. Cosmochim. Acta 67, 3871-3887 (2003).

19. Neira, N. M. et al. Cross-hole tracer experiment reveals rapid fluid flow and low effective porosity in the upper oceanic crust. Earth Planet. Sci. Lett. 450, 355-365 (2016).

20. Alt, J. C., Honnorez, J., Laverne, C. \& Emmermann, R. Hydrothermal alteration of a $1 \mathrm{~km}$ section through the upper oceanic crust, Deep Sea Drilling Project Hole 504B: mineralogy, chemistry and evolution of seawater-basalt interactions. J. Geophys. Res. 91, 10309 (1986).

21. D'Hondt, S. et al. Distributions of microbial activities in deep subseafloor sediments. Science 306, 2216-2221 (2004).

22. Inagaki, F. et al. Biogeographical distribution and diversity of microbes in methane hydrate-bearing deep marine sediments on the Pacific Ocean Margin. Proc. Natl Acad. Sci. USA 103, 2815-2820 (2006).

23. Nunoura, T. et al. Variance and potential niche separation of microbial communities in subseafloor sediments off Shimokita Peninsula, Japan. Environ. Microbiol. 18, 1889-1906 (2016).

24. Ivarsson, M., Bengtson, S. \& Neubeck, A. The igneous oceanic crust - Earth's largest fungal habitat? Fungal. Ecology 20, 249-255 (2016).

25. Orsi, W. D., Edgcomb, V. P., Christman, G. D. \& Biddle, J. F. Gene expression in the deep biosphere. Nature 499, 205-208 (2013).

26. Engelhardt, T., Kallmeyer, J., Cypionka, H. \& Engelen, B. High virus-to-cell ratios indicate ongoing production of viruses in deep subsurface sediments. ISME J. 8, 1503-1509 (2014).

27. Nigro, O. D. et al. Viruses in the Oceanic Basement. MBio 8, 1-15 (2017)

28. D'Hondt, S., Wang, G. \& Spivack, A. The underground economy (Energetic Constraints of Subseafloor Life). in Earth and life processes discovered from subseafloor environments: A decade of science achieved by the Integrated Ocean Drilling Program (IODP) 127-148 (Elsevier, 2014). 
29. Walsh, E. A. et al. Relationship of bacterial richness to organic degradation rate and sediment age in subseafloor sediment. Appl. Environ. Microbiol. 82, 4994-4999 (2016).

30. Biddle, J. F., White, J. R., Teske, A. P. \& House, C. H. Metagenomics of the subsurface Brazos-Trinity Basin (IODP site 1320): Comparison with other sediment and pyrosequenced metagenomes. ISME J. 5, 1038-1047 (2011)

31. Breuker, A., Stadler, S. \& Schippers, A. Microbial community analysis of deeply buried marine sediments of the New Jersey shallow shelf (IODP Expedition 313). FEMS Microbiol. Ecol. 85, 578-592 (2013).

32. Brandt, L. D. \& House, C. H. Marine subsurface microbial community shifts across a hydrothermal gradient in Okinawa trough sediments. Archaea 2016, 1-12 (2016)

33. Labonté, J. M., Lever, M. A., Edwards, K. J. \& Orcutt, B. N. Influence of igneous basement on deep sediment microbial diversity on the Eastern Juan de Fuca Ridge Flank. Front. Microbiol. 8, 1434 (2017).

34. Inagaki, F. et al. Exploring deep microbial life in coal-bearing sediment down to $\sim 2.5 \mathrm{~km}$ below the ocean floor. Science 349, 420-424 (2015).

35. Huber, J. A., Johnson, H. P., Butterfield, D. A. \& Baross, J. A. Microbial life in ridge flank crustal fluids. Environ. Microbiol. 8, 88-99 (2006).

36. Meyer, J. L. et al. A distinct and active bacterial community in cold oxygenated fluids circulating beneath the western flank of the Mid-Atlantic ridge. Sci. Rep. 6, 1-14 (2016).

37. Tully, B. J., Wheat, C. G., Glazer, B. T. \& Huber, J. A. A dynamic microbial community with high functional redundancy inhabits the cold, oxic subseafloor aquifer. ISME J. 12, 1-16 (2018).

38. Blair, C. C., D’Hondt, S., Spivack, A. J. \& Kingsley, R. H. Radiolytic hydrogen and microbial respiration in subsurface sediments. Astrobiology 7, 951-970 (2007).

39. Dzaugis, M. E., Spivack, A. J., Dunlea, A. G., Murray, R. W. \& D’Hondt, S. Radiolytic hydrogen production in the subseafloor basaltic aquifer. Front. Microbiol. 7, 76 (2016).

40. Gieskes, J. M. Chemistry of interstitial waters of marine sediments. Annu. Rev. Earth Planet. Sci. 3, 433-453 (1975).

41. Froelich, P. N. et al. Early oxidation of organic matter in pelagic sediments of the eastern equatorial Atlantic: suboxic diagenesis. Geochim. et. Cosmochim. Acta 43, 1075-1090 (1979).

42. Bekins, B. A., Godsy, E. M. \& Warren, E. Distribution of microbial physiologic types in an aquifer contaminated by crude oil. Microb. Ecol. 37, 263-275 (1999).

43. Barnes, R. O. \& Goldberg, E. D. Methane production and consumption in anoxic marine sediments. Geology 4, 297-300 (1976).

44. Schrum, H. N., Spivack, A. J., Kastner, M. \& D’Hondt, S. Sulfate-reducing ammonium oxidation: A thermodynamically feasible metabolic pathway in subseafloor sediment. Geology 37, 939-942 (2009).

45. Hinrichs, K. U. et al. Biological formation of ethane and propane in the deep marine subsurface. Proc. Natl Acad. Sci. USA 103, 14684-14689 (2006).

46. Teske, A., Biddle, J. F. \& Lever, M. A. Genetic Evidence of Subseafloor Microbial Communities. in Earth and life processes discovered from subseafloor environments: A decade of science achieved by the Integrated Ocean Drilling Program (IODP) 85-125 (Elsevier, 2014).

47. Hayes, J. M. \& Waldbauer, J. R. The carbon cycle and associated redox processes through time. Philos. Trans. R. Soc. Lond. Ser. B, Biol. Sci. 361, 931-950 (2006).

48. Schlesinger, W. H. \& Bernhardt, E. S. Biogeochemistry: an analysis of global change. (Academic Press, 2013).

49. Pilson, M. E. Q. An introduction to the chemistry of the sea. (Cambridge University Press, 2013).

50. Gruber, N. The Marine Nitrogen Cycle: Overview and Challenges, In Nitrogen in the Marine Environment. (Academic Press, 2008).

51. Head, I. M., Jones, D. M. \& Larter, S. R. Biological activity in the deep subsurface and the origin of heavy oil. Nature 426, 344-352 (2003).

52. Crosby, C. H. \& Bailey, J. V. The role of microbes in the formation of modern and ancient phosphatic mineral deposits. Front. Microbiol. 3, 241 (2012).

53. Moore, T. S., Murray, R. W., Kurtz, A. C. \& Schrag, D. P. Anaerobic methane oxidation and the formation of dolomite. Earth Planet. Sci. Lett. 229, 141-154 (2004).

54. Meister, P. et al. Dolomite formation in the dynamic deep biosphere: Results from the Peru Margin. Sedimentology 54, 1007-1032 (2007).

55. Paytan, A., Mearon, S., Cobb, K. \& Kastner, M. Origin of marine barite deposits: Sr and S isotope characterization. Geology 30, 747-750 (2002).

56. Kendall, B., Anbar, A. D., Kappler, A. \& Konhauser, K. O. The Global Iron Cycle. in Fundamentals of Geobiology 65-92 (John Wiley \& Sons, Ltd, 2012).

57. Lyons, T. W., Reinhard, C. T. \& Planavsky, N. J. The rise of oxygen in Earth's early ocean and atmosphere. Nature 506, 307-315 (2014).

58. Hedges, S., Blair, J. E., Venturi, M. L. \& Shoe, J. L. A molecular timescale of eukaryote evolution and the rise of complex multicellular life. BMC Evolutionary Biology 4, 1-9 (2004).

59. Jiang, Y.-Y., Kong, D.-X., Qin, T. \& Zhang, H. Y. How does oxygen rise drive evolution? Clues from oxygen-dependent biosynthesis of nuclear receptor ligands. Biochem. Biophys. Res. Commun. 391, 1158-1160 (2010).
60. Hazen, R. M. et al. Mineral evolution. Am. Mineral. 93, 1693-1720 (2008)

61. Sarmiento, J. L. \& Gruber, N. Ocean biogeochemical dynamics. (Princeton University Press, 2006).

62. Field, C. B., Behrenfeld, M. J., Randerson, J. T. \& Falkowski, P. Primary production of the biosphere: Integrating terrestrial and oceanic components. Science 281, 237-240 (1998)

63. Dunne, J. P., Sarmiento, J. L. \& Gnanadesikan, A. A synthesis of global particle export from the surface ocean and cycling through the ocean interior and on the seafloor. Global Biogeochemical Cycles 21, 1-16 (2007).

64. Anderson, L. A. \& Sarmiento, J. L. Redfield ratios of remineralization determined by nutrient data analysis. Glob. Biogeochem. Cycles 8, 65-80 (1994).

65. Burdige, D. J. Geochemistry of marine sediments. in Eos, Transactions American Geophysical Union (Princeton University Press, 2006)

66. Orcutt, B. N. et al. Oxygen consumption rates in subseafloor basaltic crust derived from a reaction transport model. Nature Communications 4, 1-8 (2013).

67. Canfield, D. E., Kristensen, E. \& Thamdrup, B. Aquatic geomicrobiology. in Advances in marine biology (Academic Press, 2005).

68. Baquiran, J. P. M. et al. Temperature and redox effect on mineral colonization in Juan de Fuca ridge flank subsurface crustal fluids. Front. Microbiol. 7, 396 (2016)

69. Smith, A. R. et al. Deep crustal communities of the Juan de Fuca ridge are governed by mineralogy. Geomicrobiol. J. 34, 147-156 (2017).

70. Jørgensen, B. B. Mineralization of organic matter in the sea bed-the role of sulphate reduction. Nature 296, 643-645 (1982).

71. Wang, G., Spivack, A. J., Rutherford, S., Manor, U. \& D'Hondt, S. Quantification of co-occurring reaction rates in deep subseafloor sediments. Geochim. et. Cosmochim. Acta 72, 3479-3488 (2008).

72. Spivack, A. J. \& Staudigel, H. Low-temperature alteration of the upper oceanic crust and the alkalinity budget of seawater. Chem. Geol. 115, 239-247 (1994)

73. Knittel, K. \& Boetius, A. Anaerobic oxidation of methane: progress with an unknown process. Annu. Rev. Microbiol. 63, 311-334 (2009).

74. Gartman, A. et al. Microbes facilitate mineral deposition in bioelectrochemical systems. ACS Earth Space Chem. 1, 277-287 (2017).

75. Canfield, D. E. Factors influencing organic carbon preservation in marine sediments. Chem. Geol. 114, 315-329 (1994).

76. Paraska, D. W., Hipsey, M. R. \& Salmon, S. U. Sediment diagenesis models: Review of approaches, challenges and opportunities. Environ. Model. Softw. 61, 297-325 (2014)

77. Hoehler, T. M., Alperin, M. J., Albert, D. B. \& Martens, C. S. Apparent minimum free energy requirements for methanogenic Archaea and sulfatereducing bacteria in an anoxic marine sediment. FEMS Microbiol. Ecol. 38, 33-41 (2001)

78. Jin, Q. \& Bethke, C. M. Cellular energy conservation and the rate of microbial sulfate reduction. Geology 37, 1027-1030 (2009).

79. Einstein, A. Über die von der molekularkinetischen Theorie der Wärme geforderte Bewegung von in ruhenden Flüssigkeiten suspendierten Teilchen. Ann. der Phys. 322, 549-560 (1905).

80. Mahmoudi, N., Beaupré, S. R., Steen, A. D. \& Pearson, A. Sequential bioavailability of sedimentary organic matter to heterotrophic bacteria. Environ. Microbiol. 19, 2629-2644 (2017).

81. Mayer, L. M. Sedimentary organic matter preservation: an assessment and speculative synthesis-a comment. Mar. Chem. 49, 123-126 (1995).

82. Petsch, S. T., Eglington, T. I. \& Edwards, K. J. ${ }^{14}$ C-Dead living biomass: evidence for microbial assimilation of ancient organic carbon during shale weathering. Science 292, 1127-1131 (2001).

83. Steen, A. D. \& Arnosti, C. Picky, hungry eaters in the cold: persistent substrate selectivity among polar pelagic microbial communities. Frontiers in Microbiology 5, 1-5 (2014).

84. Meyers, P. A. Preservation of elemental and isotopic source identification of sedimentary organic matter. Chem. Geol. 114, 289-302 (1994).

85. Estes, E. R. et al. Persistent organic matter in oxic subseafloor sediment. Nat Geosci. 12, 126-131 (2019).

86. Wehrmann, L. M. et al. Coupled organic and inorganic carbon cycling in the deep subseafloor sediment of the northeastern Bering Sea Slope (IODP Exp. 323). Chem. Geol. 284, 251-261 (2011).

87. Mayer, L. M. Surface area control of organic carbon accumulation in continental shelf sediments. Geochim. et. Cosmochim. Acta 58, 1271-1284 (1994).

88. Hedges, J. I. \& Keil, R. G. Sedimentary organic matter preservation: an assessment and speculative synthesis. Mar. Chem. 49, 81-115 (1995).

89. Pedersen, T. F. Sedimentary organic matter preservation: an assessment and speculative synthesis-a comment. Mar. Chem. 49, 117-119 (1995).

90. Ransom, B., Bennett, R. H., Baerwald, R. \& Shea, K. TEM study of in situ organic matter on continental margins: occurrence and the "monolayer" hypothesis. Mar. Geol. 138, 1-9 (1997).

91. Henrichs, S. M. Sedimentary organic matter preservation: an assessment and speculative synthesis-a comment. Mar. Chem. 49, 127-136 (1995). 
92. Jarrard, R. D., Abrams, L. J., Pockalny, R., Larson, R. L. \& Hirono, T. Physical properties of upper oceanic crust: Ocean Drilling Program Hole $801 \mathrm{C}$ and the waning of hydrothermal circulation. J. Geophys. Res.: Solid Earth 108, 1-26 (2003).

93. Jørgensen, B. B. \& Kasten, S. Sulfur cycling and methane oxidation. in Marine Geochemistry (eds. Schulz, H. D. \& Zabel, M.) 271-309 (Springer, Berlin, 2006).

94. Bowles, M. W., Mogollón, J. M., Kasten, S., Zabel, M. \& Hinrichs, K. U. Global rates of marine sulfate reduction and implications for sub-sea-floor metabolic activities. Science 344, 889-891 (2013).

95. Starnawski, P. et al. Microbial community assembly and evolution in subseafloor sediment. Proc. Natl Acad. Sci. USA 114, 2940-2945 (2017).

96. Kirkpatrick, J. B., Walsh, E. A. \& D'Hondt, S. Microbial selection and survival in subseafloor sediment. Proc. Natl Acad. Sci. 10, 1-15 (2019).

97. Heberling, C., Lowell, R. P., Liu, L. \& Fisk, M. R. Extent of the microbial biosphere in the oceanic crust. Geochem. Geophys. Geosyst. 11, 1-15 (2010).

98. Stein, C. A. \& Stein, S. Constraints on hydrothermal heat flux through the oceanic lithosphere from global heat flow. J. Geophys. Res.: Solid Earth 99, 3081-3095 (1994).

99. Hamza, V. M., Cardoso, R. R. \& Ponte Neto, C. F. Spherical harmonic analysis of earth's conductive heat flow. Int. J. Earth Sci. 97, 205-226 (2008).

100. Divins, D. L. Total Sediment Thickness of the World's Oceans and Marginal Seas. (2003). Available at: https://www.ngdc.noaa.gov/mgg/sedthick/sedthick. html. (Accessed 13th May 2018).

101. Becker, K. Measurements of the permeability of the sheeted dikes in Hole 504B. ODP Leg. 111, 317-325 (1989).

102. IODP-MI. Scientific Earth Drilling Information Service - SEDIS. Available at: http://sedis.iodp.org/. (Accessed 13th May 2018)

103. Müller, R. D., Sdrolias, M., Gaina, C. \& Roest, W. R. Age, spreading rates, and spreading asymmetry of the world's ocean crust. Geochem. Geophys. Geosyst. 8150, (2008).

104. Schulz, H. D. Quantification of Early Diagenesis: Dissolved Constituents in Marine Pore Water. in Marine Geochemistry 85-128 (Springer Berlin Heidelberg, 2000).

105. Jansen, E. \& Raymo, M. E. Leg 162: New Frontiers on Past Climates. Proceedings of the Ocean Drilling Program, Initial Reports 162, (1996).

106. D’Hondt, S., Jørgensen, B. B., Miller, D. J. \& Al., E. ODP Leg 201. Proceedings of the Ocean Drilling Program, Initial Reports 201, (2003).

107. D’Hondt, S., Inagaki, F., Alvarez Zarikian, C. A. \& The Expedition 329 Scientists. Expedition 329, South Pacific Gyre Subseafloor Life. Proceedings of the International Ocean Discovery Program (2011).

108. Thauer, R. K., Jungermann, K. \& Decker, K. Energy conservation in chemotrophic anaerobic bacteria. Bacteriol. Rev. 41, 100-180 (1977).

109. Schink, B. Energetics of syntrophic cooperation in methanogenic degradation. Microbiol. Mol. Biol. Rev. 61, 262-280 (1997).

110. Harder, J. Species-independent maintenance energy and natural population sizes. FEMS Microbiol. Ecol. 23, 39-44 (1997).

111. Wang, G., Spivack, A. J. \& D’Hondt, S. Gibbs energies of reaction and microbial mutualism in anaerobic deep subseafloor sediments of ODP Site 1226. Geochim. et. Cosmochim. Acta 74, 3938-3947 (2010).

112. Boudart, M. Consistency between kinetics and thermodynamics. J. Phys. Chem. 80, 2869-2870 (1976).

113. Dale, A. W. et al. Seasonal dynamics of the depth and rate of anaerobic oxidation of methane in Aarhus Bay (Denmark) sediments. J. Mar. Res. 66, 127-155 (2008).

114. Lovley, D. R. \& Phillips, E. J. Organic matter mineralization with reduction of ferric iron in anaerobic sediments. Appl. Environ. Microbiol. 51, 683-689 (1986).
115. Engelen, B. et al. Fluids from the Oceanic Crust support microbial activities within the deep biosphere. Geomicrobiol. J. 25, 56-66 (2008).

116. Buchwald, C. et al. Isotopic constraints on nitrogen transformation rates in the deep sedimentary marine biosphere. Glob. Biogeochem. Cycles 32, 1688-1702 (2018).

117. Wehrmann, L. M. et al. Iron-controlled oxidative sulfur cycling recorded in the distribution and isotopic composition of sulfur species in glacially influenced fjord sediments of west Svalbard. Chem. Geol. 466, 678-695 (2017).

118. Bethke, C. M., Ding, D., Jin, Q. \& Sanford, R. A. Origin of microbiological zoning in groundwater flows. Geology 36, 739-742 (2008).

119. Cohen, E. R. et al. Quantities, Units and Symbols in Physical Chemistry, IUPAC Green Book. (eds. Cohen, E. R. et al.) (RSC Publishing, 2008).

\section{Acknowledgements}

We thank Timothy Ferdelman and Richard W. Murray for helpful comments. We thank Josh Wood of the Deep Carbon Observatory for assistance with figures. This project was funded by the US National Science Foundation (through grant NSF-OCE-1130735 and the Center for Deep Dark Energy Biosphere Investigations [grant NSF-OCE-0939564]) and the National Aeronautics and Space Administration (grant NNX12AD65G). This is a contribution to the Deep Carbon Observatory (DCO). It is Center for Dark Energy Biosphere Investigations (C-DEBI) publication 454.

\section{Author contributions}

S.D. wrote the manuscript, with input from R.P., V.F. and A.J.S. R.P. created the global maps. V.F. and R.P. calculated vertical distributions of net respiration rates. S.D. and A.J.S. calculated global fluxes and developed the model of organic oxidation rate as a function of reaction affinity and diffusive distance. All authors provided editorial comments on the manuscript.

\section{Additional information}

Competing interests: The authors declare no competing interests.

Reprints and permission information is available online at http://npg.nature.com/ reprintsandpermissions/

Peer review information: Nature Communication would like to thank Wolfgang Bach and Peter Girguis for their contributions to the peer review of this work.

Publisher's note: Springer Nature remains neutral with regard to jurisdictional claims in published maps and institutional affiliations.

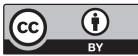

Open Access This article is licensed under a Creative Commons Attribution 4.0 International License, which permits use, sharing, adaptation, distribution and reproduction in any medium or format, as long as you give appropriate credit to the original author(s) and the source, provide a link to the Creative Commons license, and indicate if changes were made. The images or other third party material in this article are included in the article's Creative Commons license, unless indicated otherwise in a credit line to the material. If material is not included in the article's Creative Commons license and your intended use is not permitted by statutory regulation or exceeds the permitted use, you will need to obtain permission directly from the copyright holder. To view a copy of this license, visit http://creativecommons.org/ licenses/by/4.0/.

(C) The Author(s) 2019 